\title{
The Application of Membrane Vesicles for Cancer Therapy
}

\author{
Khan Salma, Jutzy Jessica M.S., Aspe Jonathan R., \\ Valenzuela Malyn May A., Park Joon S., Turay David and Wall Nathan R. \\ Loma Linda University, Dept. of Biochemistry, \\ Ctr. for Health Disparities \& Mol. Med.Loma Linda, California, \\ United States of America
}

\section{Introduction}

Cancer, a leading cause of death globally, is projected to become more prevalent in coming years due to increasing life expectancy. Among possible treatment options, the use of biomarkers especially has shown great potential as a gateway to personalized medicine, and in turn, great promise for improved diagnosis, prognosis and treatment of cancer and other diseases. However, the use of biomarkers in cancer therapeutics has thus far exhibited mild success, at best. The most common tool used for biomarker discovery is plasma proteomics due to the accessibility of blood samples and the rapid development of highly sensitive proteomics technologies. However, other body fluids such as urine may also be a reservoir for important marker proteins.

Extracellular membrane vesicles ranging in diameter of $30-1000 \mathrm{~nm}$ and originating from various cellular origins have been increasingly recognized for their participation in a variety of both normal and pathological cellular processes. Regardless of their cell type of origin these membrane bound vesicles or exosomes provide a protected and controlled internal microenvironment outside the cell for metabolic objectives of the host cell to be carried out at a distance from the host cell. They are also believed to be instrumental in cell-cell and cellextracellular communication. Moreover, while knowledge of exosome biogenesis and physiological relevance remains limited, accumulating evidence suggests that their bioactivity may be clinically applicable in cancer therapeutics. One recent work suggests that the use of exosomes in immunotherapy may prime the immune system to recognize and kill cancer cells and thus could form a viable basis for the development of novel cancer vaccines.

This chapter will review current knowledge pertaining to exosomes, describe possible uses of exosomes in immunotherapy, and address challenges and future directions in bringing exosome-based cancer vaccines or immunotherapies closer to clinical reality.

\section{Exosome biogenesis, secretion and physiologic considerations}

Since their description in the process of reticulocyte maturation almost a quarter century ago (Johnstone et al., 1987), exosomes; the intralumenal vesicles (ILV's) of multivesicular bodies (MVB's), have gained significant notoriety as evidenced by the nearly 10-15 fold rise in the 
amount of publications devoted to the subject just within the past decade (Raimondo et al., 2011).

Many types of vesicles have been described in the literature having quite heterogeneous size, protein content, RNA content and origin. As a result there have been many names given to these different vesicle types (Table 1) (Ronquist \& Brody, 1985; Ronquist \& Frithz, 1986; Rooney et al., 1993; Arienti et al., 1997; Thery et al., 2006; Lehmann et al., 2008; Schiller et al., 2008; Simpson et al., 2008; Skog et al., 2008; Dashevsky et al., 2009; Di Vizio et al., 2009; Haubold et al., 2009; Jansen et al., 2009; Nilsson et al., 2009; Duijvesz et al., 2010). Unfortunately, the different names given to these vesicles lead to much confusion and it is still unclear if all of the different vesicles are unique in biological function or if they represent a sliding scale of one entity (Duijvesz et al., 2010). Exosomes are nanometer sized lipid bound vesicles derived from late endosomes contained in MVB's. They are characterized by their size $40-100 \mathrm{~nm}$, density ranging from $1.13 \mathrm{~g} / \mathrm{ml}$ to $1.19 \mathrm{~g} / \mathrm{ml}$ on a sucrose gradient (Record et al., 2011) and their specific protein content (heat shock proteins, tetraspanins, Rab proteins, etc) Figure 1. Exosomes are secreted by both hematopoietic (eg dendritic cells, lymphocytes, mast cells) and non-hematopoietic cells such as fibroblasts, intestinal epithelium, neurons and various tumor cells. Exosomes have been isolated from serum and other biological fluids such as urine, ascitic fluid, amniotic fluid and even cerebrospinal fluid (Vella et al., 2008). Exosome biogenesis involves an inward budding of the limiting membrane of late endosomes, also known as multivesicular bodies (MVBs) (Figure 2), concurrent protein sorting into these budding exosomes, and subsequent splitting (scission) of these microvesicles (Keller et al., 2006). As a consequence, the nascent exosome contains the inner leaflet of the limiting membrane, membrane associated proteins, both native and recruited, and some amount of cytosol and cytosolic proteins.

\begin{tabular}{|c|c|c|c|c|}
\hline Vesicle & $\begin{array}{l}\text { Size } \\
(\mathrm{nm})\end{array}$ & Marker Proteins & Function & Reference \\
\hline Exosomes & $50-150$ & $\begin{array}{l}\mathrm{CD} 9, \mathrm{CD} 63 \text {, CD81, CDS2, } \\
\text { annexins, and RAB proteins }\end{array}$ & $\begin{array}{l}\text { Antigen presentation, immune } \\
\text { regulation, metastatic activity }\end{array}$ & $\begin{array}{l}\text { Jansen FH, et al., 2009; Nilssen J, et al., 2009; } \\
\text { Simpson Rl, et al, 2008; Thery C, et al, 2006 }\end{array}$ \\
\hline Prostasomes & $50-500$ & $\begin{array}{l}\mathrm{CD} 13, \mathrm{CD} 46, \mathrm{CD} 55, \mathrm{CD} 59 \\
\text { annexins, and RAB proteins }\end{array}$ & $\begin{array}{l}\text { Immunosuppressive and } \\
\text { sperm cell motility improving }\end{array}$ & 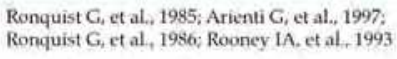 \\
\hline Oncosomes & $50-500$ & Signal transduction proteins & Function unknowvn & Di Vizio D, et al., 2009 \\
\hline Microvessicles & $100-1000$ & $\begin{array}{l}\text { Integrins, selectins, CD40 } \\
\text { ligands }\end{array}$ & $\begin{array}{l}\text { Procoagulation and } \\
\text { anticoagulation }\end{array}$ & Skog J, et al., 2008; Lehmann BD, et al., 2008 \\
\hline $\begin{array}{l}\text { Ectosomes } \\
\text { (microparticles) }\end{array}$ & $50-1000$ & $\begin{array}{l}\mathrm{CRI} \text { and proteolytic } \\
\text { enzymes, no } \mathrm{CD} 63\end{array}$ & $\begin{array}{l}\text { Procoagulation and } \\
\text { anticoagulation }\end{array}$ & $\begin{array}{l}\text { Haubold K, et al, 2009; Dashersky O, et al. } \\
\text { 2009; Duijuesz D, et al., } 2011\end{array}$ \\
\hline $\begin{array}{l}\text { Membrane } \\
\text { Particles }\end{array}$ & $\begin{array}{l}P 4: 30-80 \\
P 2: 600\end{array}$ & CD133, no CD63 & $\begin{array}{l}\text { Stem cell marker, possible role } \\
\text { in tissue development and } \\
\text { maintenance }\end{array}$ & Marzesco AM, et al., 2005 \\
\hline $\begin{array}{l}\text { Exosome-like } \\
\text { Vesicles }\end{array}$ & $20-50$ & TNFR1 & $\begin{array}{l}\text { Constitutive production of } \\
\text { soluble cy tokine receptors may } \\
\text { be regulated }\end{array}$ & Hawari FI, et al, 2004 \\
\hline $\begin{array}{l}\text { Apoptotic } \\
\text { Vesicles }\end{array}$ & $50-500$ & $\begin{array}{l}\text { Histones } \mathrm{HI}, \mathrm{H} 2 \mathrm{~A}, \mathrm{H} 2 \mathrm{~B}, \mathrm{H3} \\
\text { and } \mathrm{H} 4 \text { as well as DNA \& } \\
\mathrm{RNA} \text { no cytochrome c, p53 } \\
\text { or } \mathrm{Hsp} 70\end{array}$ & $\begin{array}{l}\text { Autoantigen seclusion/ } \\
\text { isolation }\end{array}$ & Thery C, et al., 2001; Schiller M et al, 2008 \\
\hline
\end{tabular}

Table 1. Characteristics of different types of microvessicles. 

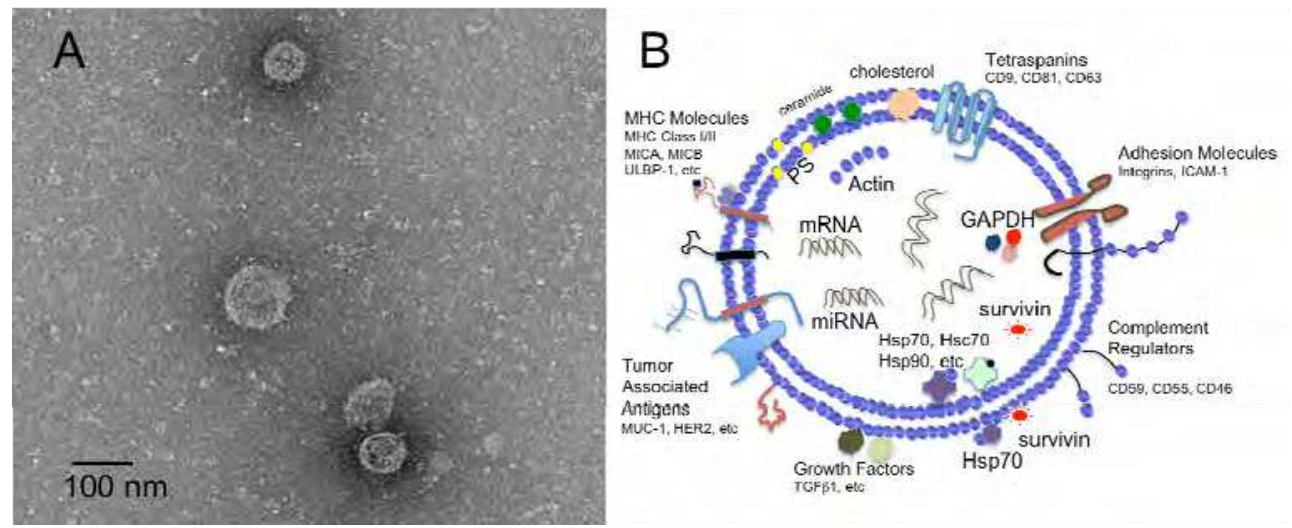

Fig. 1. Tumor derived exosomes (TEX). A. Electron microscopy revealed 50-100 nm sized microvesicles (Khan et al., 2011). B. Diagram depicting a typical TEX (modified from JP Mitchel, exosomes in cancer immunology).

The presence of specific proteins within and on the vesicle suggest the existence of a protein sorting mechanism during its formation. Some of these proteins are shared by exosomes derived from different sources and used to identify these vesicles during proteomic analysis. In our laboratory, we have consistently used the lysosomal associated membrane protein LAMP1 (common to exosomes from a wide variety of cells) as a positive control for exosome presence in western blot analysis (Khan et al., 2011).

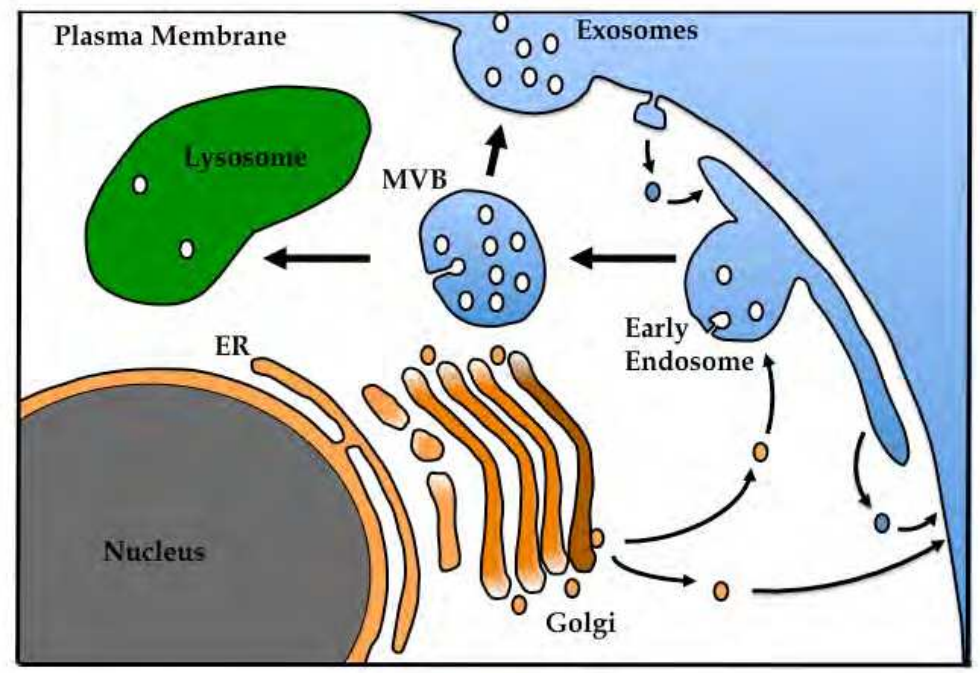

Fig. 2. Protein loading and release by exosomes. Endocytosed surface proteins as well as a subset of cytosolic proteins are taken by the endosomal system. Those destined for release as exosomes or for lysosomal degradation are sorted into lumenal vesicles called multivesicular bodies (MVB). 


\subsection{ESCRT-dependent protein sorting}

The specific protein content of exosomes can be exploited to identify these exosomes and the cell-types from which they are derived via proteomic analysis. The fact that the exosome's protein content can be used as an identifier suggests the existence of a protein sorting mechanism during its formation. Endosomal Sorting Complex Required for Transport (ESCRT), comprised of a series of three protein complexes: ESCRT I, ESCRT II, and ESCRT III (Figure 3), is suspected to play a critical role in sorting proteins into exosomes at the endosomal limiting membrane.

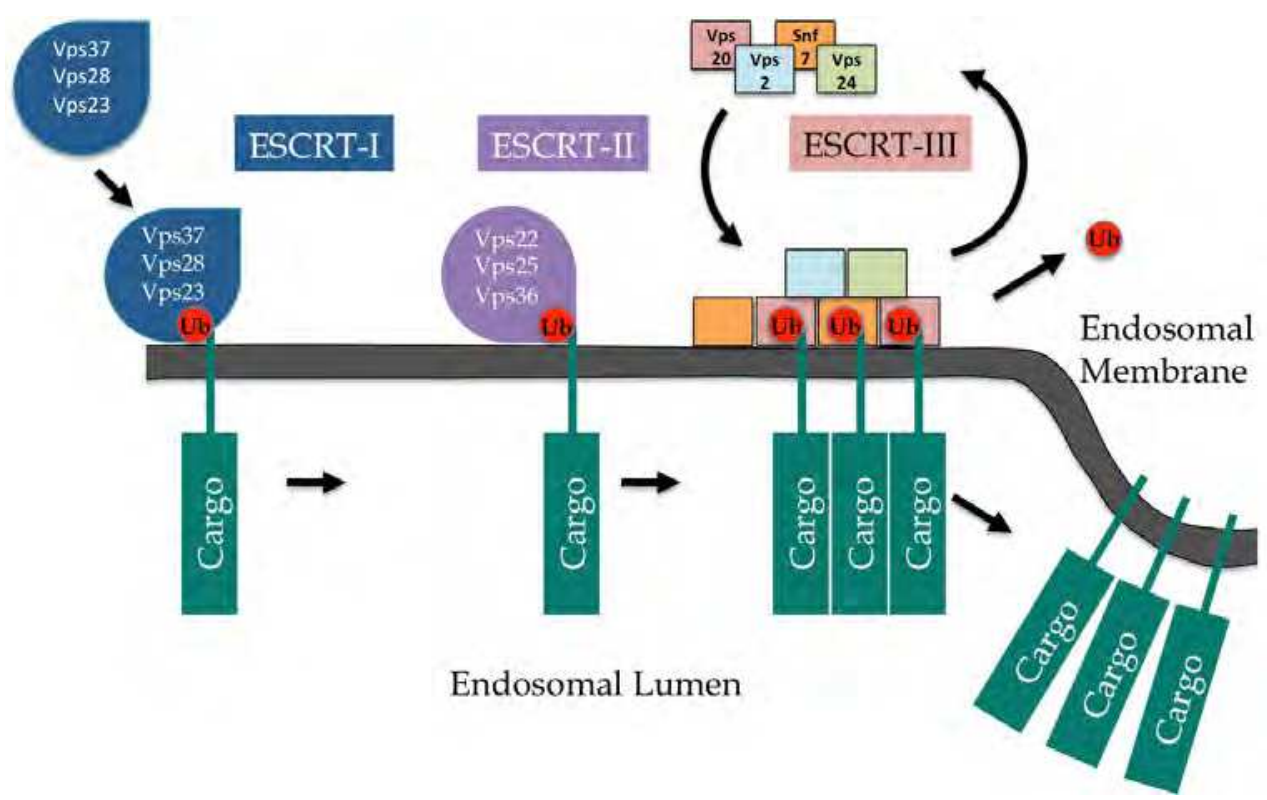

Fig. 3. Ubiquitin marks cargo proteins for endosomal sorting.

Monoubiquitination appears to mark cargo proteins for protein sorting within the MVBs. In yeast, recruitment of ubiquitinated cargo proteins depends on a class of proteins known as class E Vps (Vacuolar Protein Sorting) proteins that have been highly conserved from yeast to mammals - at least one mammalian homolog has been identified for each yeast class member (Babst, 2005). In the yeast model, Vps 27, is thought to complex on the endosomal membrane's outer leaflet with clathrin and ubiquitin-binding proteins, such as Golgiassociated, $\gamma$-adaptin homologs, Arf-binding (GGA) proteins, to form an endosomal clathrin coat that recruits monoubiquitinated cargo to the inner leaflet of the endosomal membrane. This complex recruits the ESCRT I complex from the cytoplasm and transfers to it the ubiquitinated cargo. ESCRT I then activates ESCRT II, which in turn occasions the oligomerization of Vps 2, Vps 20, Vps 24, and Snf 7 to form the ESCRT III complex and transfers to ESCRT III the ubiquitinated cargo. ESCRT III continues to accumulate and concentrates the cargo into still-budding exosomes of the MVB (Babst, 2005). The deubiquitinating protein Doa4 is then recruited into the complex where it functions to remove the ubiquitin from the cargo protein (Luhtala \& Odorizzi, 2004). The ESCRT III 
complex subsequently dissociates from the cargo when the ATPase Vps 4 binds, thus releasing the cargo protein into the budding exosome.

\subsection{Other modes of protein sorting}

Other exosomal proteins, for which no ESCRT mechanisms have been described, may be incorporated into the exosome via varying levels of co-sorting. For example, tetraspanins may sort into exosomes due to their affinity for exosomal membrane components like sphingolipids and ceramides and may follow these phospholipids to further aggregate into lipid raft domains (de Gassart et al., 2003). Protein-protein associations also contribute to co-sorting. MHC Class II molecules can associate with tetraspanins and be co-sorted into exosomal membranes (Blanc \& Vidal, 2010). Some evidence also suggests lipid co-sorting into exosomes. The exosomal lipid LBPA (Lysobisphosphatidic Acid) can sort into exosomal membranes by interaction with the exosomal protein Alix. When present in media, LBPA was also shown to assist with the formation of vesicles in the MVBs (Matsuo et al., 2004).

Hematopoietic cells including dendritic cells, lymphocytes and mast cells, and nonhematopoietic cells such as fibroblasts, intestinal epithelial cells, neurons and various tumor cells secrete exosomes. Exosome release from cells may follow a constitutive versus an inducible mode of secretion. The constitutive pathway utilizes the trans-golgi network, after which the vesicles travel through the cytoplasm via an intricate tubular network and eventually are released into the extracellular space (Ponnambalam \& Baldwin, 2003). The inducible mode involves the release of preformed vesicles contained in MVBs. Such release may be dependent on known cellular triggers of vesicle release, such as increased intracellular calcium levels (Savina et al., 2003). Other triggers, such as cellular depolarization, have also been described. These events culminate in the fusion of MVB membrane with the cell membrane and subsequent exosome release into the extracellular space.

Exosomes interact with target cells via specific receptors present on these target cells (Losche et al., 2004). The exosome thus exerts its effect either via receptor-receptor interaction or internalization of the exosome with subsequent interaction of the exosome content with the recipient cellular machinery (Record et al., 2011).

As will be described in other sections of this chapter, exosomes influence immune cells both in normal and abnormal states such as cancer. Furthermore RNA contained in exosomes could be translated within the recipient cell and as a result exert an epigenetic influence (BajKrzyworzeka et al., 2006). In this regard, exosomes mimic viral particles by directing host cellular processes to its advantage. The role of exosomes in inflammatory conditions has recently been questioned after platelets and macrophage derived microparticles/exosomes were found in the lipid core of artherosclerotic plaques (Leroyer et al., 2008). It is of interest to better understand the precise pro-inflammatory and thrombotic roles of exosomes and potentially use them as therapeutic targets in these conditions. Finally, the discovery of exosomes in urine has opened up the possibility of exosomal proteins being used as biomarkers for disease. It was recently shown that decreased levels of exosomal aquaporin-1 correlates with renal ischemia-reperfusion injury (Sonoda et al., 2009). What makes this prospect exciting is the relative abundance of urine that can be obtained without an invasive procedure.

\subsection{Summary}

Exosomes are small membrane bound vesicles of endocytic origin that are released by most cells. The purpose for release seemed at first to be to discard membrane proteins and those 
believed to be resistant to lysosomal degradation. Now, it is believed that they mediate intercellular communication without the need for direct cell-to-cell interaction.

\section{Existence of secreted membrane vesicles in cancers}

Tumors are known to shed membrane vesicles (Taylor \& Gercel-Taylor, 2005). In particular, human and mouse tumor cells have been shown to secrete tumor cell-derived exosomes (TEX), constitutively into the extracellular space (Wolfers et al., 2001). The morphology, density and certain membrane markers expressed, such as LAMP1, MHC class I, HSP70 and HSP80, on the released TEX are similar to the dendritic cell-derived exosomes (DEX) (Andre et al., 2002b) which will be discussed later. Despite similarities to DEX, there are differences in the molecular profiles and biological roles of TEXs, both of which give an indication of the cell of origin (Wieckowski \& Whiteside, 2006). The specific protein content found on and within exosomes not only reflects their origin, but in addition, establishes their functional role (Zitvogel et al., 1998) (Table 2). TEX secreted from neoplastic cells express diverse tumor antigens, which signifies the type of tumor cells from where TEXs were released (Iero et al., 2008). In-vitro, it has been shown that TEX released from breast carcinoma cells contain HER2, while carcinoembryonic antigen (CEA) was found in the exosomes secreted from colon carcinoma cells, and proteins MelanA/Mart-1 and gp100 that are expressed in melanoma cells are found on the released TEX (Andre et al., 2002b; Andreola et al., 2002). This phenomenon is also evident in-vivo, where plasma from cancer patients contain membrane vesicles that are characterized by the expression of tumor antigens which reflect the tumor of origin (Hegmans et al., 2004; Mears et al., 2004).

When immunocompetent and nude mice were pre-treated with murine mammary TEX, an accelerated growth of the tumor was observed (Liu et al., 2006). This observation led to various studies to try to elucidate the role of secreted membrane vesicles in cancer. TEX can be described as "multi-purpose carriers" which have important roles in the communication, protection, as well as the exchange of genetic information with neighboring cells (Nieuwland \& Sturk, 2010). The production and secretion of TEX is important for the tumor. They serve a protective function, have a supportive role in the survival and growth of the tumor cells, are involved in the promotion of host tissue invasion and subsequent metastasis, and facilitate evasion from the immune response (Valenti et al., 2007; Anderson et al., 2010). Acting in a paracrine fashion, the diverse function of TEX is speculated to be due to the various bioactive molecules found within and on the vesicles having a strong influence on the surrounding environment (Hegmans et al., 2004; Mears et al., 2004; van Niel et al., 2006; Iero et al., 2008).

The promotion of angiogenesis is due in part to the upregulation of vascular endothelial growth factor (VEGF) (Skog et al., 2008) and release of matrix metalloproteinases (MMPs) in neighboring, even distant endothelial cells, which are brought by TEX containing tetraspanin family members (Gesierich et al., 2006), epithelial growth factor receptor (EGFR) (Al-Nedawi et al., 2009), platelet-derived tissue factor (TF) (Osterud, 2003) or developmental endothelial locus-1 protein (Hegmans et al., 2004). TEX has also been implicated in the further growth of tumor by the exchange of genetic material. mRNA was detected within exosomes released from glioblastoma cells. Neighboring microvascular endothelial cells that take up the exosomes and translate the mRNA become liable for further tumor growth leading to the stimulation of angiogenesis (Skog et al., 2008). In addition, tissue invasion and stromal remodeling can be facilitated by proteases and MMP transport and release via exosomes (Ginestra et al., 1998; Graves et al., 2004). 


\begin{tabular}{|c|c|c|}
\hline Cancer Type & Protein & References \\
\hline $\begin{array}{l}\text { Breast adenocarcinoma } \\
\text { (BT-474 } \\
\text { MDA-MB-231, TS/A, H-2, } \\
\text { P815) }\end{array}$ & ERBB2* /HER2* & $\begin{array}{l}\text { (Andre et al., 2002b; } \\
\text { Koga et al., 2005) }\end{array}$ \\
\hline Cervical Cancer (heLa) & Survivin, HSP 70, HSP 90 & (Khan et al., 2011) \\
\hline $\begin{array}{l}\text { Colorectal Cancer } \\
\text { (LIM1215, HT29, SW403, } \\
\text { 1869COL, AND CRC28462, } \\
\text { LIM1215) }\end{array}$ & $\begin{array}{l}\text { GPA 33*, CEACAM5*, EFNB1* } \\
\text { annexins, ARFs*, Rabs*, ADAM10*, } \\
\text { CD44* NG2 ephrin-B1, MIF*, b- } \\
\text { catenin, junction plakoglobin } \\
\text { galectin-4, RACK1*, and tetraspanin- } \\
\text { 8, FASL* AND TRAIL* FASLG* } \\
\text { TNFSF10* }\end{array}$ & $\begin{array}{l}\text { (Andreola et al., 2002; } \\
\text { Abusamra et al., 2005b; } \\
\text { Huber et al., 2005; Taylor } \\
\text { \& Gercel-Taylor, 2005; } \\
\text { Choi et al., 2007; } \\
\text { Simpson et al., 2009) }\end{array}$ \\
\hline Glioma Cancer & EGFR* & (Al-Nedawi et al., 2009) \\
\hline $\begin{array}{l}\text { Melanoma } \\
\text { (Fon and Mel-888) }\end{array}$ & $\begin{array}{l}\text { TRP*GP100*MART-1* } \\
\text { Mel-CAM*FASLG*TNFSF10* } \\
\text { A33*, CEA, EGFR*, ADAM10*, } \\
\text { dipeptidase 1 ephrin-B1, hsc70, } \\
\text { tetraspanins, ESCRT proteins } \\
\text { (integrins, annexins, Rabs, and } \\
\text { GTPases) }\end{array}$ & $\begin{array}{l}\text { (Andre et al., 2002b; } \\
\text { Mears et al., 2004; } \\
\text { Abusamra et al., 2005b) } \\
\end{array}$ \\
\hline Mesothelioma & \begin{tabular}{|l|l} 
PLVAP* & \\
\end{tabular} & (Hegmans et al., 2004) \\
\hline Ovarian & ERBB2* & $\begin{array}{l}\text { (Andre et al., 2002b; } \\
\text { Andreola et al., 2002; } \\
\text { Koga et al., 2005) }\end{array}$ \\
\hline Prostate & $\begin{array}{l}\text { FASLG* } \\
\text { TNFSF10* }\end{array}$ & $\begin{array}{l}\text { (Huber et al., 2005; Kim } \\
\text { et al., 2005) }\end{array}$ \\
\hline Squamous cell cancer & $\begin{array}{l}\text { FASLG } \\
\text { TNFSF10 }\end{array}$ & $\begin{array}{l}\text { (Taylor et al., 2006; } \\
\text { Martinez-Lostao et al., } \\
\text { 2010) }\end{array}$ \\
\hline
\end{tabular}

Table 2. Protein content on and within exosomes reflects their origin and establishes their functional role. Cell surface A33 antigen precursor (GPA 33); Carcinoembryonic antigenrelated cell Adhesion molecule 5 (CEACAM5); Ephrin-B1 (EFNB1); ADP-ribolysing factor (ARF), Ras-Gprotein superfamily (Rabs), A disintegrin and metaloprotease (ADAM10), Macrophage Migration inhibitory factor (MIF), Receptor for activated C-kinase (RACK1), 5,6-Dihydroxyyindole-2 carboxylic acid oxidase (TRP); Epidermal-growth factor receptor (EGFR); Receptor tyrosine-protein kinase erbB-2 (ERBB2); Plasmalemma vesicle associated protein (PLVAP); Melanocyte Protein Pmel 17 (GP100); Melanoma Antigen Recognized by T cells 1 (MART-1), Mel-CAM, TNF-ligand superfamily member 10 (TRAIL) TNF-ligand superfamily member 6 (FasL). 
Recent studies have shown that TEX provide a protective role to the cancer cells, which can be manifested in different ways. Survivin, a member of the inhibitor of apoptosis (IAP) protein family, was found to be released from tumor cells via exosomes (Khan et al., 2011). The protective role of TEX can be attained by the accumulation and packaging of chemotherapeutic drugs or its metabolites into the vesicles, thus decreasing cellular levels of the drug, a factor leading to drug resistance (Shedden et al., 2003; Safaei et al., 2005). This phenomenon has been observed in various cancer cells. Cisplatin enhanced the shedding of the vesicle from melanoma cells (Chen et al., 2006a), while doxorubicin was found in the exosomes released from ovarian carcinoma cells (Shedden et al., 2003).

Despite the beneficial roles of TEX for the tumor cells and the tumor microenvironment, TEX can be a useful tool for detecting the malignant condition. Serum levels of exosomes taken from cancer patients are significantly increased. These vesicles taken from serum (Ginestra et al., 1999), as well as from malignant tumor fluids, such as ascites fluids (Adams et al., 2005), pleural effusions (Andre et al., 2002b) and urine (Nilsson et al., 2009), positively correlate with the tumor progression.

\subsection{Constitutive and inducible vesicle secretion in cancer and cancer therapy}

In the tumor microenvironment, various changes are taking place, which could have an effect on the release of vesicles, such as exosomes. Environmental changes, such as stress induced by chemo- and radio-therapy, can modulate TEX release and the biome they contain. This phenomenon may induce the tissues to adapt to changes taking place in the microenvironment (Thery et al., 2009). Tumor cells that have undergone radiation or chemotherapy treatment have been shown to increase the release of TEX (Yu et al., 2006; Lehmann et al., 2008). Interestingly, when treated with chemotherapeutic agents, there is a significantly enhanced membrane vesicle secretion in chemoresistant cells compared to chemosensitive cells. This activity may be a factor leading to drug resistance (Shedden et al., 2003; Safaei et al., 2005).

Chemotherapy and radiation (Chen et al., 2006b) treatment lead to DNA-damaging conditions. In this state, the p53 pathway is activated, leading, among various other changes physiologically, to an induced expression of the transmembrane protein tumor suppressoractivated pathway 6 (TSAP6). TSAP6 is an important cellular component as it regulates the secretion of protein via the non-classical pathway or the ER/Golgi-independent protein secretion pathway needed for the enhanced release of exosomes (Nickel, 2003; Yu et al., 2006; Lespagnol et al., 2008). Normally, the secretion of exosomes in various cell types happens at a low rate. However, when p53 is activated, endosomal compartment activities are activated. Simultaneously, there is an increased expression of TSAP6, inducing the release of exosomes at a higher rate (Yu et al., 2009) (Figure 4). It is suggested that following p53 activation, exosomal release may act as a 'detoxifier' to expel unwanted chemotherapeutic agents (Shedden et al., 2003; Safaei et al., 2005; Chen et al., 2006b; Lespagnol et al., 2008). Communication to the microenvironment is the other proposed role of TSAP6 and exosomal release after p53 activation, which may act as a warning signal to the neighboring cells, the immune system, and the extracellular matrix, that there are abnormal intracellular events happening (Lespagnol et al., 2008; Yu et al., 2009).

\subsection{Summary}

TEX can be used as an important biomarker for the disease, which will give information not only on the disease progression, but on the tumor type. As previously mentioned, TEX 
express specific tumor antigens which reflect the protein content of the tumor, giving an indication of the tumor type. The content of these vesicles can also be useful as markers for the aggressiveness of the disease.

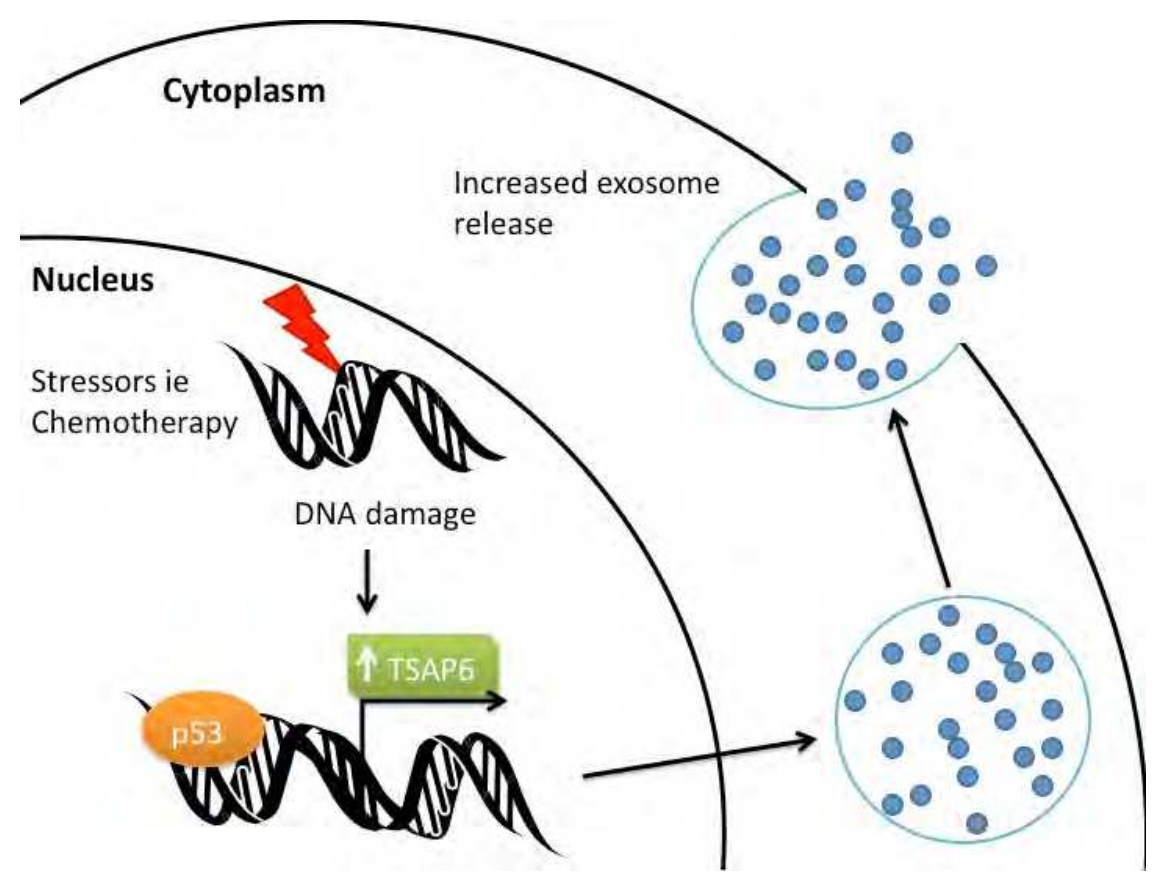

Fig. 4. Activation of p53 by DNA damage induces the expression of TSAP6 which enhances exosome-mediated secretion.

\section{Proteome of cancer membrane vesicles}

Mass spectrometry-based proteomic tools coupled with advanced purification methods for exosomes, has allowed more in-depth proteome analyses, contributing immensely to our understanding of the molecular composition of exosomes. Proteomic analysis of exosomes from diverse cell types, including cancers has revealed a common set of membrane and cytosolic proteins, suggesting the evolutionary importance of these membrane particles. In addition, exosomes express an array of proteins that reflect the originating host cell. The excessive release of exosomes in tumor cells, as evidenced by their increased levels in body fluids during the late stage of a disease and their overexpression of certain tumor cell biomarkers, suggests an important role of exosomes in diagnosis and biomarker studies (Simpson et al., 2009).

By proteomic analysis we can enrich low abundance membrane proteins from underrepresented conventional cell lysates and unfractionated biological fluids. Identification of a conserved set of common proteins that are essential for vesicle biogenesis, structure and trafficking mechanisms can be explored. We can also detect cell-specific biomarkers. These concepts suggest that analyzing the composition and abundance of such proteins in exosomes may be useful to reveal different cell behaviors. 


\subsection{Proteomics of cell-type dependent exosomes}

Exosomes have a unique protein composition that varies depending on cellular origin (Table 2). Analysis of exosomes from a wide variety of cells and body fluids have been identified. Exosomes from various cancer cells expose Fas ligand (FasL, CD95L), a ligand of the death receptor Fas (CD95), which induces T-cell apoptosis and diminishes the function of adaptive immune cells (Andreola et al., 2002; Huber et al., 2005). It was shown that a modest correlation exists between lymph node infiltration and tumor burden and the numbers of circulating FasL-exposing exosomes in blood from patients with oral squamous cell cancers (Kim et al., 2005). Exosomes from lymphoblastoma cells exposed latent membrane protein-1 (LMP-1), another immune suppressing transmembrane protein, thereby inhibiting leukocyte proliferation. In addition, low numbers of circulating exosomes, in cancer patients, stained positive for MUC1, a cancer cell antigen, and glycoprotein IIIa (integrin $\beta 3$ ), which is mainly present on platelets and platelet-derived exosomes. Exosomes are released after fusion of exosomes from malignant epithelial cells with platelets (Tesselaar et al., 2007). Alternatively, platelet-derived exosomes were shown to transfer integrins to breast and lung cancer cells (Janowska-Wieczorek et al., 2001; Janowska-Wieczorek et al., 2005). Thus, cancer cells can fuse with non-cancer cell-derived exosomes, thereby receiving lipids and membrane specific proteins which may help them escape from immune surveillance.

Degradation of the extracellular matrix (ECM) is essential for tumor growth (Hotary et al., 2003). Exosomes expose and contain proteases, including matrix metalloproteinase 2 (MMP2) and MMP-9 and its zymogens, and urokinase-type plasminogen activator (uPA). Neovascularization is also responsible for the increased entry of tumor cells into the circulation and metastasis. It is believed that tumor and stromal cells secrete angiogenic factors such as VEGF and basic fibroblast growth factor (bFGF) and that tumor-associated angiogenesis occurs by the action of these factors (Carmeliet, 2005). Furthermore, growing evidence suggests that exosomes derived from tumor cells and platelets also possess angiogenic activities. Vesicular components such as sphingomyelin, CD147, tetraspanin-8, VEGF, and bFGF are likely involved in exosome-mediated neovascularization (Kim et al., 2002; Brill et al., 2004; Gesierich et al., 2006; Millimaggi et al., 2007).

In a colorectal cancer cell line study, several exosomal proteins have been identified that are believed to be involved in tumor-associated angiogenesis: ADAM 10, CD44, NG2, ephrinB1, macrophage migration inhibitory factor (MIF), RACK1, and tetraspanin-8 (Dong-Sic et al., 2007). Clinical exosome analysis may also prove useful for solid cancers (Mathivanan et al., 2010). Using exosomes from ovarian carcinoma cell lines, malignant ascites and sera from ovarian carcinoma patients, it was found that malignant ascites-derived exosomes cargo tumor progression related proteins (L1CAM, CD24, ADAM10 and EMMPRIN). It was also observed that exosomes move systemically via the blood stream (Keller et al., 2009). Therefore, if some membrane proteins are typically and specifically expressed by a certain tumor, their detection on circulating exosomes, (which could be isolated from only $1 \mathrm{~mL}$ of blood), may be exploited for diagnostic purposes as an early signal of cancer presence. Proteomic analysis of exosomes was also performed on human mesothelioma cell lines and malignant pleural effusions. Bard and colleagues, described exosomes which contained antigen presenting molecules, cytoskeletal proteins, and signal tranduction-involved proteins were in mesothelioma, lung, breast, and ovarian cancers. In addition, SNx25, BTG1, PEDF, and Thrombospondin were also identified (Bard et al., 2004). 
Characterization of urinary exosomal composition may be proposed as a potential source of diagnostic markers in bladder cancer. Two different approaches (Smalley et al., 2008; Welton et al., 2010) were taken to characterize these exosomes. In the first, urine exosomes were isolated from a limited number of individuals with bladder cancer and their protein composition compared to that of healthy controls. Eight proteins were found elevated, among which five have been linked to the EGF receptor pathway (Smalley et al., 2008). In the second study, extensive steps were taken to produce high purity and quality-assured exosome preparations prior to beginning proteomics workflows. Working with conditioned media from cultured bladder cancer cell lines, 350 proteins were identified. Eighteen were proven to be present in exosomes isolated from the urine of three bladder cancer patients (Welton et al., 2010). This suggests that conditioned media from cultured cell lines could represent an interesting starting model to detect exosomal proteomic alterations, which must then be confirmed in vivo, using biological fluids from a wide cohort of patients, in order to supply a non-invasive source for biomarker discovery.

Exosomes prepared from urine of prostate cancer patients contain typical markers of such a tumor (PSA and PCA3) (Mitchell et al., 2009; Nilsson et al., 2009). Moreover, $\delta$-catenin immunoreactivity was identified in vesicles prepared from culture media of PC3 cells and found significantly increased in prostasomes of the urine of prostate cancer patients (Lu et al., 2009).

\subsection{Summary}

Studies confirm that urinary exosome protein profiling is an important topic and may be a valuable tool for biomarker discovery in the field of urinary tract pathology. Proteomic approaches to investigate membranous vesicles and exosomes are still immature. However, they show a great potential for future developments in the diagnostic and prognostic applications.

\section{Targeting interactions of membrane vesicles with neighboring tumor microenvironment}

Tumor cells release large quantities of exosomes containing procoagulant, growth regulatory, and oncogenic cargo, which can be transferred throughout the cancer cell population and to transformed stromal cells, endothelial cells and possibly to the inflammatory infiltrates. These events likely impact tumor invasion, angiogenesis, metastasis, drug resistance, and cancer stem cells. Instead of physical contact, the influence of exosomes on the target cell may also involve pericellular discharge/activation of the bioactive cargo (Dolo et al., 2005; Hendrix et al., 2010; Muralidharan-Chari et al., 2010). For instance, this may involve proteolytic remodelling of the extracellular microenvironment, modulation of ligand-receptor interactions, and a variety of other effects that could change the behaviour of target cells and properties of their surroundings (Hendrix et al., 2010) (Figure 5). In some instances, such interactions could be rather complex and multifactorial. The recently described Rab27B-regulated exosomal release of MMPs and HSP90a from metastatic cancer cells is believed to control invasive cellular behaviour by inducing changes in the extracellular matrix (ECM) as well as through modification of growth factor responses (Hendrix et al., 2010). Likewise, procoagulant exosomes may facilitate tumor initiation, invasion, and dissemination by activating the clotting cascade extracellularly and coagulation-dependent signalling intracellularly (Milsom et al., 2007). Exosome-mediated 
emission of various factors including tetraspanins, chemoattractants, adhesion molecules and proteases from cancer cells, platelets, and other cellular sources contributes to metastatic regulation in several experimental systems (Janowska-Wieczorek et al., 2005; Jung et al., 2009). As mentioned earlier, exosomes may also act as important reservoirs of cytokines and mediators of inflammatory and immune responses (Bianco et al., 2009; Thery et al., 2009).

\subsection{Mediators of intercellular communication}

Contact with the cell death ligand (FasL) exposed on certain tumor cell-derived exosomes is lethal for Fas-expressing lymphoid cytotoxic effector cells, a process implicated in the induction of immunotolerance in colorectal cancer and possibly other malignancies (Albanese et al., 1998). These influences may affect recipient cells via a random distribution of exosomes in tissue and body fluids, or more directional exosome homing/uptake mechanisms. For instance, an acidic $\mathrm{pH}$ commonly present in hypo-perfused areas of solid tumors may lead to localized disruption of exosomes and consequent discharge of their proangiogenic and pro-inflammatory cargo such as VEGF and other factors (Taraboletti et al., 2006). Exosomes may also be directed to specific sites due to the molecular addresses they carry on their surfaces (Celi et al., 2004; Zhou et al., 2008; Xiao et al., 2009). The nature, directionality, and efficiency of this molecular exchange depends on several factors. For instance, the physical properties of vesicular plasma membranes affect the fusion rate between exosomes and target cells, which may increase their exosome uptake under acidic $\mathrm{pH}$ (Parolini et al., 2009). In some instances, exosome transfer could also be directed by specific molecular addresses, for example, a high concentration of phosphatydyl serines (PS) on the surface of certain exosomes (e.g. ectosomes or procoagulant microparticles) may enable their recognition by PS receptors (PSRs) on the surface of specific types of target cells. Many of such PSRs have been described within the context of phagocytosis of apoptotic cells by mononuclear cells; examples of such PSRs include Tim1, Tim4, stabilin 2 and BAI1 (Park et al., 2007; Zhao et al., 2010), at least some of which could be expressed more widely and may be involved in the uptake of exosomes. Indeed, blocking PSRs often obliterates exosome incorporation by endothelial cells, platelets and cancer cells (Del Conde et al., 2005; Al-Nedawi et al., 2008; Al-Nedawi et al., 2009). A corollary to this point would be that phagocytes could be particularly susceptible to molecular influences of PS-positive exosomes, beyond their simple destruction. It has also been proposed that Tim $1 / 4$ receptors on two adjacent cells could allow formation of exosome bridges, thereby promoting additional indirect intercellular interactions (Xiao et al., 2009). Similarly, the presence of PSGL-1 (P-selectin ligand) on the surface of procoagulant exosomes directs them to Pselectin-expressing platelets and endothelial cells (Thomas et al., 2009).

\subsection{Oncosomes: Oncogene-driven vesiculation}

During malignant transformation, the action of mutant oncogenes, such as K-ras, EGFR, or its constitutively active mutant EGFR (variant III) (EGFRvIII), as well as several others, appear to stimulate the formation and release of exosomes (Yu et al., 2005; Al-Nedawi et al., 2008). Similarly, the activation or loss of specific tumor suppressor proteins appears to impact cellular vesiculation either positively or negatively (Yu et al., 2005; Yu et al., 2006). While the exact nature of the signalling pathways involved in oncogene-driven exosome biogenesis remains largely unknown, recent studies have begun to shed more light on the underlying processes. For instance, in cultures of prostate cancer cells, elevated exosome 
production was detected in association with increased oncogenic activity of protein kinase $B$ (PKB/Akt), or upon stimulation with growth factors (EGF), and depending on the status of the actin regulating protein known as diaphanous related formin 3 (DRF3) (Di Vizio et al., 2009). In this case, inhibition of DRF3 expression through RNA interference enhanced the rate of exosome formation, and membrane blebbing activity, suggesting that DRF3 may be an inhibitor of ectosome release (Di Vizio et al., 2009). Interestingly, DRF3 expression is lost during the progression of prostate cancer to metastatic disease, which suggests an intriguing link between oncogenesis, vesiculation and metastasis (Di Vizio et al., 2009).

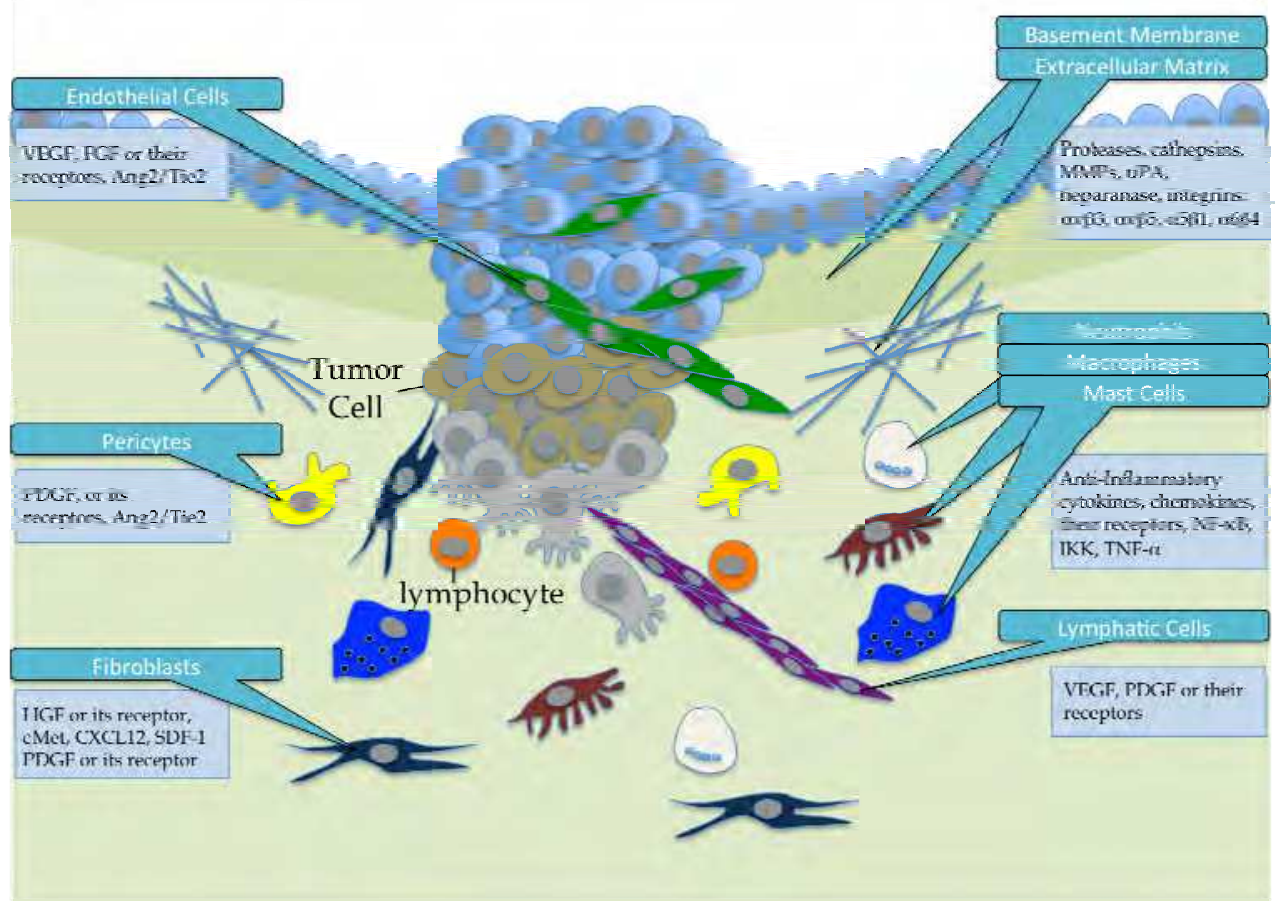

Fig. 5. Tumor microenvironment. The heterotypic interactions within the tumor microenvironment and their give and take of exosomes and their contents provide many targets for possible therapy. The goal of targetting these interactions will interrupt the heterotypic signaling that would thus deprive the cancer cells of the support they have within the tumor microenvironment.

\subsection{Effect of TEX on tumor microenvironment}

Exosome release by colorectal cancer cells is a function of K-ras and p53 status (Yu et al., 2005). It is noteworthy that oncoproteins not only stimulate exosome formation but also become incorporated into their cargo (Al-Nedawi et al., 2008; Al-Nedawi et al., 2009). As a result, oncogene-containing exosomes (sometimes refered to as oncosomes) may serve as vehicles that carry oncogenic cargo and mediate its transfer between cells (Al-Nedawi et al., 2009). At least four different modes of such oncogenic transfer have been described: (a) intercellular passage of active oncoproteins (Al-Nedawi et al., 2008), (b) transfer of oncogenic mRNA transcripts 
(Skog et al., 2008), (c) exchange of oncogenic miR and/or (d) passage of genomic sequences containing oncogenic DNA (Bergsmedh et al., 2001). In many instances, this horizontal transfer may have marked biological (transforming) consequences. Thus, oncosomes containing EGFRvIII may emanate from malignant tumor cells and be taken up by their indolent counterparts inducing their growth, survival, and clonogenic and angiogenic capacity (AlNedawi et al., 2008). These exosomes may also act on endothelial cells and reprogram their responses such that they exhibit an increase in angiogenic activity (Skog et al., 2008) or switch to an autocrine mode of secretory pathway, e.g. by turning on VEGF production (Al-Nedawi et al., 2008). Indeed, blocking exosome uptake using the Annexin V analogue (Diannexin) is associated with a measurable anti-angiogenic effect in vivo (Al-Nedawi et al., 2008). In chronic lymphoblastic leukaemia (CLL), exosomes containing AXL kinase conditioned the bone marrow stroma to support disease progression (Ghosh et al., 2010). These and similar effects identify exosomes as possible effectors of oncogenic and proangiogenic field effects, long postulated to exist in cancer (Slaughter et al., 1953; Al-Nedawi et al., 2009) and viewed as a mechanism of cell recruitment to the malignant process.

\subsection{Intercellular exchange}

Interactions between exosomes and their target cells may depend on the specific ligandreceptor recognition events. For instance, platelets take up procoagulant exosomes in a manner that depends on the expression of P-selectin and its ligand (PSGL-1) on the respective surfaces (Falati et al., 2003). After the uptake, exosome-associated material was shown to penetrate into the cytoplasm of the acceptor cell (Skog et al., 2008) or to remain on the cell surface, potentially in the immediately active form (Del Conde et al., 2005; AlNedawi et al., 2008). Interestingly, cloaking PS by exposure of exosomes to Annexin V often obliterates their uptake by target cells. Recent studies suggested that exosomal transfer would encompass multiple effectors at once (Skog et al., 2008). Such exosomal exchange could contribute to tumor angiogenesis by mechanisms dependent on transfer of oncogenes (Rak, 2010) (e.g., EGFRvIII4 or mRNA), but possibly also through bidirectional trafficking of other molecules (e.g., VEGFRs, Tie, Notch), including ligands traditionally assumed to act almost exclusively in a cell-associated manner (Dll4, ephrins) (Kerbel, 2008). This prototype has been already validated in the case of exosomal emission of coagulation factors (e.g., tissue factor-TF21), chemokine receptors (Mack et al., 2000) adhesion molecules (Falati et al., 2003), immunomodulators (Valenti et al., 2007), cell surface antigens (Dolo et al., 2005), intact RNA species (Ratajczak et al., 2006; Valadi et al., 2007), and oncogenic proteins (Koga et al., 2005; Al-Nedawi et al., 2008; Sanderson et al., 2008).

\subsection{Summary}

So far in the literature, exosomal cargo associated proteins and their importance in angiogenesis, inflammation, proteolysis regulators, membrane receptors, soluble factors, oncoproteins and tumor suppressors, lipids, nucleic acids are described briefly. Therefore, exosomes represent an integral part of both physiological regulation and disease pathogenesis, which may influence new therapeutic and diagnostic modalities.

\section{Membrane vesicles and antigen presentation}

As described earlier in this chapter, various cell types release exosomes, which contain a proteomic sampling from the cell of origin. Proteins within exosomes can be presented as 
antigens to the immune system and, when derived from certain cell types, are capable of presenting antigens to immune cells directly. Antigen presentation by antigen presenting cells (APCs) requires several important steps to elicit an immune response: 1 . the APC internalizes and processes the antigen, 2. the processed antigen is inserted into Major Histocompatibility Complex (MHC) molecules and displayed on the cell surface, 3. MHC molecules interact with $\mathrm{T}$ cell receptors to start a signaling cascade to activate the T cell (Kim et al., 2004). Dendritic cells are the primary APC type that stimulates T cells in vivo, which requires MHC molecules on the dendritic cell, as well as expression of co-stimulatory molecules that enhance T cell activation, such as CD40, CD80 and CD86 (Kim et al., 2004). Like many other cell types, dendritic cells release membrane vesicles, particularly exosomes, which help modulate the immune response (Chaput et al., 2006; Schorey \& Bhatnagar, 2008; Thery et al., 2009).

\subsection{Antigen presentation by immune cell exosomes}

Antigen presenting cells, such as dendritic cells and B cells, release exosomes equipped with MHC class I and class II molecules that allow direct presentation of antigens to cytotoxic and helper T cells, respectively (Kim et al., 2004; Chaput et al., 2006). Antigens processed by APCs are loaded into MHC molecules and the MHC-antigen complex is released into the extracellular space within exosomes. These exosomes then travel throughout the body and induce an immune response by stimulating antigen-specific T cells. In addition to MHC molecules, APC exosomes express surface co-stimulatory molecules CD40, CD80 and CD86 to enhance $T$ cell activation (Raposo et al., 1996). The ability of exosomes to induce a $T$ cell response is dependent on the expression of these molecules, as introduction of antibodies against CD40, CD80 and CD86 inhibit antigen presentation and T cell activation by APC exosomes. Additionally, the tetraspanin molecule CD54 (ICAM1) plays a crucial role in this process by enhancing exosome-T cell contact through its interaction with CD11a (LFA-1) on the T cell (Kim et al., 2004). This interaction allows MHC and co-stimulatory molecules to bind to their receptors on the $\mathrm{T}$ cells long enough to provide sufficient signaling. As observed with inhibition of the co-stimulatory molecules, antibody blockade of CD54 on exosomes dramatically reduces T cell activation by APC exosomes (Kim et al., 2004).

\subsection{Transfer of antigens by exosomes}

In addition to their ability to present processed antigens, exosomes can also transfer antigens from one cell to another. Exosomes containing cellular antigens are taken up by APCs, where the antigens are processed and inserted into MHC molecules for presentation (Obregon et al., 2006). This is a very important mechanism in disease states, where infected or malignant cells release exosomes into the bloodstream that can be processed and presented by APCs throughout the body to induce an immune response (Bhatnagar \& Schorey, 2007). In cancer, TEXs are taken up by APCs and activate tumor-specific T cells (Andre et al., 2002a). In vitro studies have shown that when T cells are incubated with TEX in the presence of naïve dendritic cells, both helper and cytotoxic T cells are activated in an antigen-specific manner (Thery et al., 2009). Additionally, in vivo vaccination studies comparing TEX and irradiated tumor cells showed a stronger immune response in animals vaccinated with TEXs. These studies have led to two clinical trials, which will be discussed in detail later. 


\subsection{Summary}

Antigen presentation to $\mathrm{T}$ cells is the first and most critical step in the adaptive immune response. The ability of exosomes to supply antigens to dendritic cells for presentation as well as present antigens directly via exosomal MHC molecules is an important mechanism for detection of infection and malignancy. Induction of anti-cancer responses via tumorreleased exosome antigens is likely a key mechanism in immune surveillance to prevent tumor progression. Whether this can be utilized in tumor immunotherapies is under investigation and could prove useful in combination therapies.

\section{Antigen-independent roles of membrane vesicles in immune responses}

Antigen presentation by exosomes is primarily an immunostimulatory process, however exosomes have many antigen-independent functions that can both stimulate and inhibit the immune system (Schorey \& Bhatnagar, 2008; Thery et al., 2009). These roles are dependent on the type of cell the exosomes originate from and the molecules they express (Andre et al., 2002a; Abusamra et al., 2005a; Xiang et al., 2009; Chalmin et al., 2010; Szajnik et al., 2010; Zhang et al., 2011). In this way exosomes are important for proper immune function and immune regulation, but can also be hijacked by malignant cells to prevent detection by the immune system.

\subsection{Immune cell exosomes induce immune responses}

Dendritic cell exosomes (DEXs) are vital for stimulation of the adaptive immune response by their presentation of antigen to T cells (Figure 6), but induction of the humoral immune response is as important a function (Chaput et al., 2006). DEXs have been shown to stimulate Natural Killer (NK) cell responses critical to the clearance of infection and malignancy (Viaud et al., 2009). This function is mediated by the expression of interleukin-15 receptor alpha (IL-15Ra) and Natural Killer Group 2D (NKG2D) ligands on dendritic cell exosomes. Interleukin-15 (IL-15) is a cytokine that stimulates NK cell activation and proliferation. Exosomal IL-15Ra can bind IL-15 in the extracellular space and deliver it to NK cells by exosomal binding to NKG2D on the surface of the NK cells (Viaud et al., 2009). Delivery of IL-15 in this manner significantly increases NK cell responses in vitro and in mice injected with autologous DEXs (Thery et al., 2009; Viaud et al., 2009). Because of their critical importance to tumor clearance, NK cell stimulation by DEXs could provide therapeutic benefits by increasing NK cell numbers in cancer patients.

\subsection{Tumor cell exosomes and the immune response}

The role of TEX in the progression of cancer is multifaceted, as they can affect tumor growth, invasion and metastasis, and therapy resistance. In addition to influencing other malignant cells, TEXs have significant effects on the immune response, both positive and negative.

\subsubsection{Exosomes from heat-shocked tumor cells induce immune activation}

The release of exosomes from normal and malignant cells is increased by heat shock and stress, with amplified proportions of Hsps within the exosome (Schorey \& Bhatnagar, 2008). Culture of dendritic cells with exosomes from heat-shocked tumors resulted in higher expression of CD40, CD80 and CD86 than in dendritic cells cultured with control immune 
cell exosomes or non-heat shocked tumor exosomes (Chen et al., 2006c). Additionally, the dendritic cells treated with heat shocked TEXs exhibited increased production of proinflammatory cytokines tumor necrosis factor alpha (TNFa), IL-1 $\beta$, and IL-12 (Chen et al., 2006c). This is thought to be mediated by the increased amount of Hsps in the heat-shocked TEXs, though the exact mechanism is still under investigation.

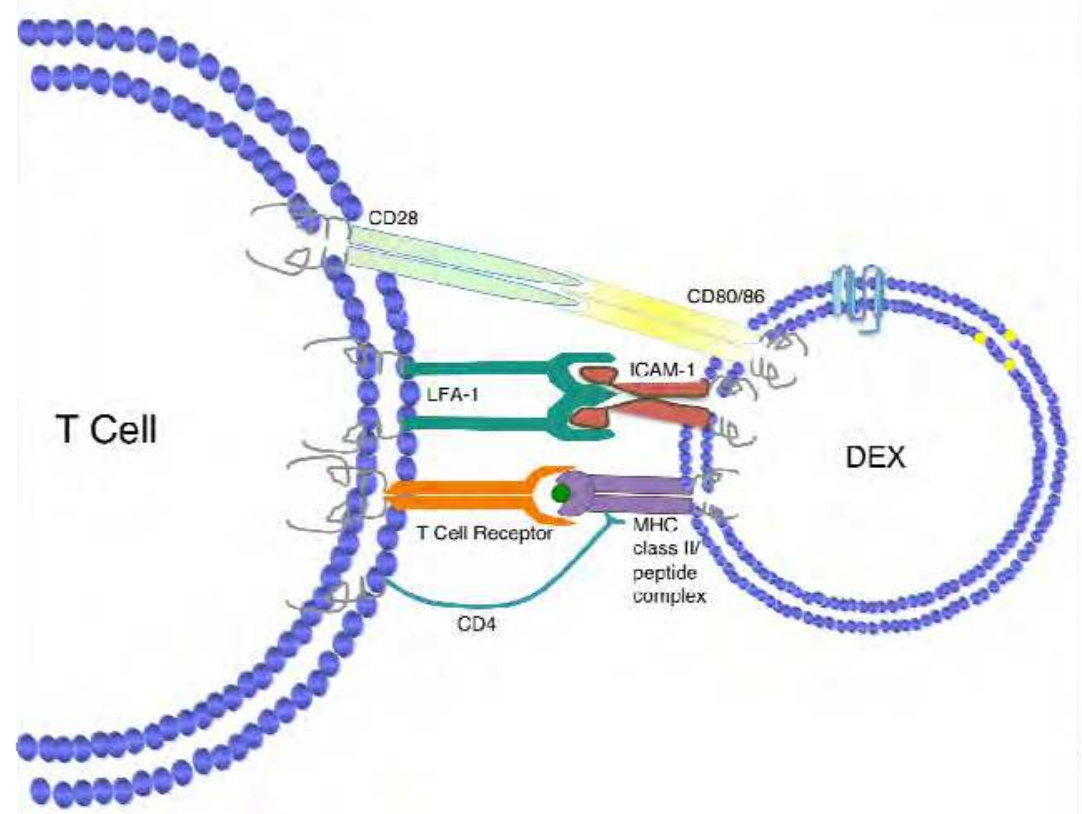

Fig. 6. Dendritic cell-derived exosomes interact with T cells through MHC class I, II, tetraspanins such as CD9, CD63, CD81 and through co-stimulatory molecules such as CD86.

\subsubsection{Tumor cell exosomes inhibit natural killer cells via NKG2D}

NK cells kill cancer cells by release of granules and perforins (Figure 7). NK cell activity is often lost in cancer patients, resulting in a reduced ability of the immune system to eliminate malignant cells (Clayton et al., 2008; Viaud et al., 2009; Ahiru et al., 2010). The NK cell receptor NKG2D is important in regulation of NK cell function, with some ligands stimulating and others inhibiting cytotoxic function (Clayton et al., 2008). As discussed earlier, DEXs expressing activating NKG2D ligands can enhance NK cell function and promote tumor clearance (Viaud et al., 2009). Other NKG2D ligands, such as MHC class Irelated chain A (MICA) can reduce NK cell function. Tumor cells abuse this normal ligand by upregulating MICA on the cell surface as well as on TEXs (Ahiru et al., 2010). Ovarian cancer exosomes expressing high levels of MICA were shown to decrease NK cell function in vitro by reducing their NKG2D receptor expression and their responsiveness to activating NKG2D ligands (Ahiru et al., 2010). This reduction in NK cell function is highly detrimental to the anti-tumor response and is one of many mechanisms by which tumors escape immune detection (Thery et al., 2009). 


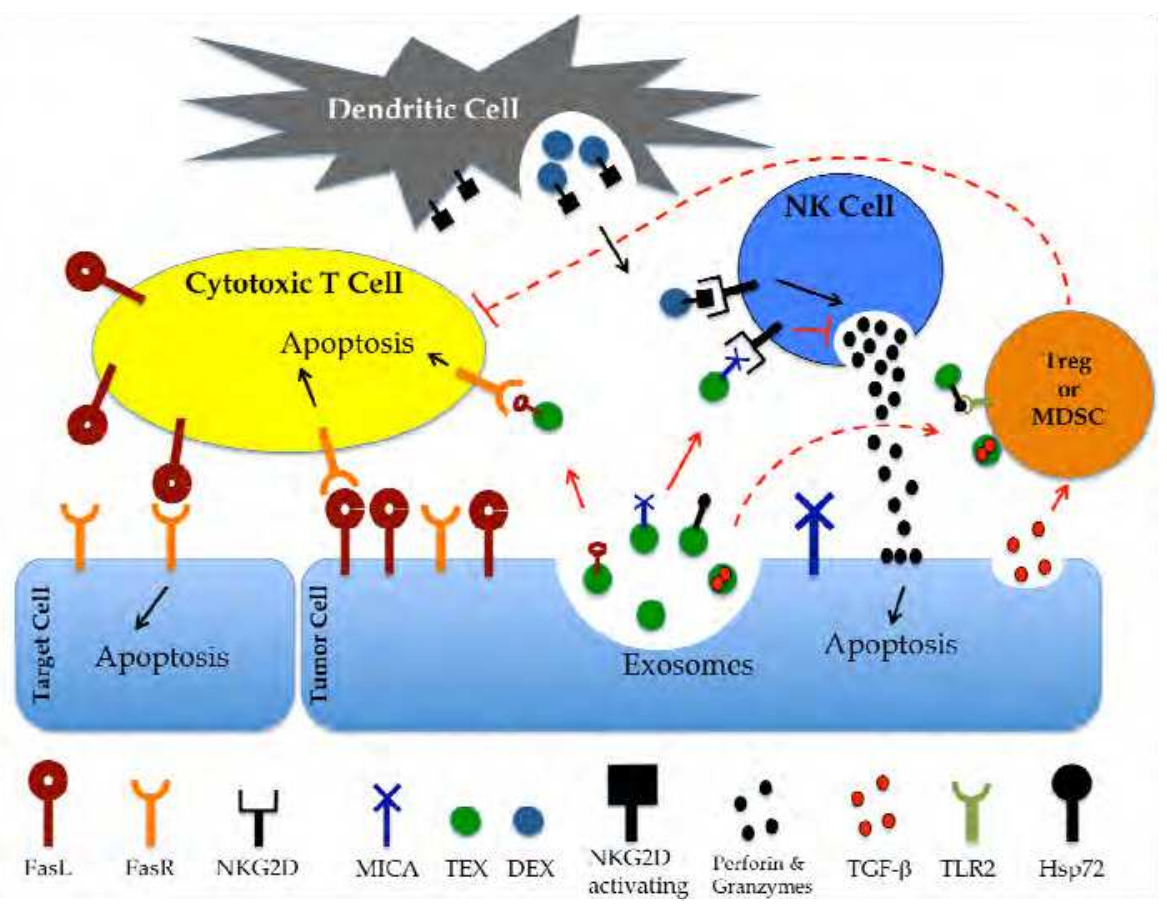

Fig. 7. DEX and TEX play opposing roles with regard to immune cell activation and prohibition.

\subsubsection{Fas ligand expression on tumor cell exosomes induce immune cell apoptosis}

Cytotoxic immune cells like cytotoxic T cells express Fas Receptor (FasR; CD95) and Fas ligand (FasL; CD95L) that allow them to induce apoptosis in target cells. Several cancer types including colon and ovarian carcinoma and melanoma cells express FasL to induce death of the very immune cells that attempt to kill them (Koyama et al., 2001). This is a primary mechanism of tumor-immune escape that prevents the immune system from eliminating transformed cells, resulting in disease progression. To further prevent cytotoxic killing by $\mathrm{T}$ cells, TEXs have been found to express high levels of surface-bound FasL (Abusamra et al., 2005a). Release of FasL via exosomes allows the tumor to kill FasRexpressing immune cells at distant sites, as well as in the tumor microenvironment, further preventing tumor clearance. Interestingly, although both helper and cytotoxic $\mathrm{T}$ cells express FasR, exosomes containing FasL preferentially induce apoptosis in cytotoxic $\mathrm{T}$ cells and not in helper T cells (Abusamra et al., 2005a). The mechanism behind this is not fully understood, but may be due to favored interactions between exosomes and cytotoxic $\mathrm{T}$ cells due to other exosomal surface molecules (Figure 7).

\subsubsection{Tumor exosomes induce suppressive immune cell phenotypes}

Immune suppression within the tumor microenvironment prevents cytotoxic attack and promotes tumor progression. Like FasL and NKG2D inhibition, increasing immunosuppressive cell types can reduce cytotoxic immune responses. Two primary 
inhibitory cell types have been implicated in cancer progression: regulatory T cells (Tregs) (Szajnik et al., 2010) and myeloid derived suppressor cells (MDSCs) (Xiang et al., 2009). These cell types inhibit both helper and cytotoxic $\mathrm{T}$ cell responses and reduces their production of inflammatory cytokines like interferon gamma (IFN- $\gamma$ ). Large numbers of immune cells are found within the tumor microenvironment, but Tregs and MDSCs are far more prominent in cancer patients than in healthy patients, leading to the hypothesis that immune suppression can be induced by the tumors (Xiang et al., 2009; Szajnik et al., 2010). Tumor cells can directly induce regulatory populations by secreting transforming growth factor beta (TGF- $\beta$ ), which promotes differentiation of naïve T cells and myeloid precursor cells into their respective suppressive phenotypes. A similar mechanism is utilized by tumors to induce Tregs and MDSCs within the tumor microenvironment and the periphery by secretion of TGF- $\beta$ in exosomes (Xiang et al., 2009; Chalmin et al., 2010; Szajnik et al., 2010). Ovarian carcinoma derived exosomes were found to induce CD $4{ }^{+} \mathrm{CD} 25^{+} \mathrm{Foxp} 3^{+}$Tregs from CD4 ${ }^{+}$CD25- naïve T cells in vitro (Szajnik et al., 2010). This was found to be dependent on the presence of TGF- $\beta$ and IL-10 in the exosomes and was inhibited by addition of neutralizing antibodies to both cytokines. In a similar study, mouse bone marrow myeloid precursor cells were shown to take up TEXs, inducing their differentiation into CD $11 \mathrm{~b}^{+} \mathrm{Gr}-1^{+}$ myeloid derived suppressor cells. Exosomal expression of TGF- $\beta$ and prostaglandin E2 (PGE2) was shown to induce this differentiation, which was inhibited by antibody neutralization (Xiang et al., 2009). The suppressive function of existing MDSCs is also increased by TEXs. Interaction of Hsp72 on the exosome with Toll-like receptor 2 (TLR2) on the MDSC induces Stat3 signaling to induce their immunosuppressive functions (Chalmin et al., 2010). By increasing immunosuppressive cell types, TEXs can prevent attack by cytotoxic cells (Figure 7).

\subsection{Summary}

Exosomes can have important antigen-independent effects on immune cells that vary with the cell type they are derived from as well as the state of the cells upon release. DEXs and TEXs can stimulate immune responses, which could provide therapeutic benefits. In contrast, tumor derived exosomes from several cancer types have been shown to prevent cytotoxic attack on the tumor by FasL-induced $T$ cell death, NKG2D ligand-mediated suppression of NK cells and through induction of immune suppressor cells like Tregs and MDSCs. How TEXs can be utilized or inhibited therapeutically remains to be seen, but currently is an active area of research.

\section{Immune responses induced by in vitro purified membrane vesicles in vivo}

Many studies described in the Sections 6 and 7 were performed using membrane vesicles and exosomes isolated and introduced to immune cell cultures in vitro. Before these findings can be utilized therapeutically, they must be confirmed in in vivo animal models. Results from these animal studies have demonstrated the importance of exosomes in immune modulation and are currently being implemented in clinical trials.

\subsection{Vaccination with tumor exosomes prevent tumor growth in mice}

Early studies in tumor vaccination utilized irradiation-killed tumor cells with limited success. With the discovery of TEXs, mouse vaccination studies with TEXs were shown to be more effective at generating tumor-specific $\mathrm{T}$ cell responses than irradiated tumor cells. 
Additionally, vaccination of mice with exosomes containing ovalbumin resulted in delayed growth of ovalbumin-expressing tumors and induced pro-inflammatory Th1 $\mathrm{T}$ cell responses. As described in Section 7.2, exosomes isolated from heat-shocked cancer cells are more immunogenic in vitro. Using heat-shocked TEXs for immunization in mice showed similar immunogenicity, with $80 \%$ of mice remaining tumor free after challenge. While these studies have provided the groundwork for cancer vaccines, the immunosuppressive functions of cancer exosomes have caused many to be skeptical of their use as vaccine.

\subsection{Dendritic cell exosomes containing tumor antigens induce anti-tumor immune responses}

The use of DEXs as artificial antigen presenting cells can elicit strong antigen-specific $\mathrm{T}$ cell responses (Kim et al., 2004). Mouse studies using DEXs pulsed with tumor peptides resulted in the activation of tumor-specific T cells, proliferation of NK cells and tumor regression (Kim et al., 2004; Chaput et al., 2006). Utilization of this technology with great success in murine studies has led to the development of several clinical trials using autologous DEXs as a treatment in cancer patients (Figure 8).

\subsubsection{Melanoma phase I trial}

A Phase I trial using dendritic cell exosomes to induce tumor regression was evaluated in 15 patients with metastatic melanoma (Escudier et al., 2005). Autologous monocytes were isolated from patients by leukapheresis and differentiated in vitro to dendritic cells. These dendritic cells were cultured, exosomes isolated from the culture medium and pulsed with peptides from the tumor antigen MAGE3 (Escudier et al., 2005). Patients received escalating doses of cryopreserved exosomes and their tumor progression and immune responses monitored. All 15 patients completed therapy but only 1 had specific T cell responses. Skin and lymph node mass reduction was observed in 5 of 15 patients and 7 of 15 patients showed increased NK cell activity (Escudier et al., 2005; Thery et al., 2009).

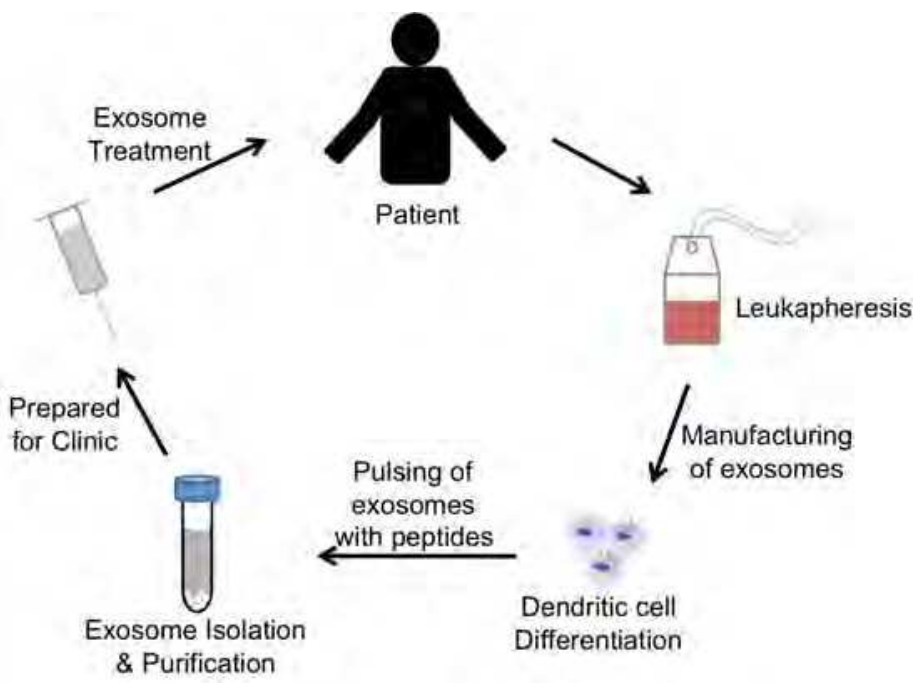

Fig. 8. Dendritic cell exosomes can be harvested and used in immunotherapy. 


\subsubsection{Non-small cell lung cancer phase I and II trials}

A similar trial to the melanoma study was performed in Stage III and IV non-small cell lung cancer (NSCLC) (Morse et al., 2005). Of the 13 patients enlisted in the trial, 9 finished the treatments and no toxicity was observed. Immune responses to MAGE3 was observed in 3 of 9 patients, with MAGE3-specific T cells only detected in 1 patient and while an increase in Treg cells was observed in 2 patients (Morse et al., 2005). This trial concluded that dendritic cell exosomes are safe for use therapeutically, but that better responses may result from including Treg inhibitors in the treatment. A Phase II trial has begun adding IL-15R and NKG2D to the exosomes as well as Treg inhibitor therapy in NSCLC patients whose disease has been stabilized by chemotherapy (Thery et al., 2009).

\subsection{Summary}

The use of exosomes as a cancer therapeutic has been demonstrated to be effective in murine studies and safe by Phase I clinical trials. Although some benefit was seen in patient trials, making these exosomal therapies more effective will likely require combination immunotherapies, chemotherapies and radiation. The use of exosomes to induce anti-cancer responses presents an exciting new field in cancer immunotherapy.

\section{Membrane vesicles as therapeutic agents}

Secreted microvesicles, known as exosomes, provide a form of cell to cell signaling in which the recipient cell can be modified by the contents of the delivered exosomes. The contents (cytosolic proteins, lipids, siRNA, miRNA, DNA, etc) (Tan et al., 2010; Khan et al., 2011) are protected and stably delivered unlike those secreted into the extracellular matrix (Pap et al., 2010); thus securing the bioactivity of the delivered contents. Exosomes could be an attractive tool as an immunotherapeutic as they maintain much of the anti-tumor activity of a dendritic cell with the advantage of a cell free vehicle. Understanding that exosomes are involved in many levels of tumorigenesis, and potential strategies against this form of cellular communication has led to the creation of potential therapeutics against exosomes.

TEXs are a protective measure for tumor cells that aids in survival, growth, invasion, metastasis, and evasion of the immune system (Clayton et al., 2007; Valenti et al., 2007; Anderson et al., 2010; Khan et al., 2011). Taxol and vinca alkaloids are well known chemotherapeutic agents, but they also limit exosome release via the microtubule formation. Exosome formation has also been shown to be blocked by decreasing acidity of the microcellular environment (Iero et al., 2008; Pap et al., 2010). Prevention of exosome formation involves a broad variety of proteins and is essential for life in all cells. Therefore any inhibition of exosomes within the body could lead to unwarranted side effects (Pap et al., 2010). It was thought that inhibition or treatment focused against TEXs and its ability to aid tumor cells could bear significant benefit to patients, but that was overshadowed by the realization that exosomes could potentially be employed as biomarkers and diagnostic tools of malignancy in blood (Anderson et al., 2010) and urine (Nilsson et al., 2009). One such study analyzed the correlation between serum PSA and urinary-exosomes, but none was observed. However, the data suggests that healthy donor urinary-exosomes were negative for PSA, PSMA, and 5T4 (Mitchell et al., 2009).

Realizing that exosomes are secreted/released by a wide variety of cell types (Skokos et al., 2001; Wolfers et al., 2001; Chaput et al., 2004b; Tan et al., 2010; Khan et al., 2011) including 
immune cells and tumor cells, many studies set out to manipulate exosomes for cancer therapy, specifically immunotherapy. Ever since B lymphocytes were described to contain MHC class II molecules and stimulate CD4+ T cells (Raposo et al., 1996), studies have suggested exosomes may have an immunogenic role. Currently, DEXs from pulsed dendritic cells are under investigation for their ability to enhance and prime the immune system against tumor cells. Dendritic cells activate $\mathrm{T}$ cell responses through direct dendritic to $\mathrm{T}$ cell contacts. However, exosomes secreted by dendritic cells are also able to stimulate $\mathrm{T}$ cells (Zitvogel et al., 1998).

\subsection{Anti-cancer therapy}

The importance of exosomes in cell to cell communication can be seen in their antigen presenting ability. Seminal work during the late 1990's showed DC's pulsed/loaded with cancer antigens or tumor peptides could yield DEXs which elicited better immune responses towards tumor cells (Zitvogel et al., 1998; Wolfers et al., 2001; Couzin, 2005; Chaput et al., 2006; Tan et al., 2010). The immune response was due to DEXs displaying the appropriate MHC class I molecules and tumor peptides. In fact, DC can be pulsed with both MHC class I and II, therefore effectively priming T cells against tumors (Thery et al., 2002; Andre et al., 2004; Chaput et al., 2004a; Mignot et al., 2006) as well as stimulating the activation and proliferation of NK cells (Clayton et al., 2007; Viaud et al., 2009). Current literature suggests that MHC class I and II containing exosomes are potential cell-free cancer vaccines (Zitvogel et al., 1998; Andre et al., 2004; Chaput et al., 2004a; Tan et al., 2010). Unlike current clinical cancer vaccines, exosomes are not technically vaccines as they are preventative and not therapeutic. The prophylactic vaccines are only effective against oncogenic viruses and do not treat the cancer directly, not to mention too expensive for the average patient (Tan et al., 2010). Treatment of tumors with DEXs has had beneficial results such as initiation of immune response (Couzin, 2005), tumor growth suppression (Zitvogel et al., 1998), tumor shrinking (Viaud et al., 2009), and tumor rejection (Wolfers et al., 2001; Mignot et al., 2006). Exosomes are a better alternative than DC in terms of therapy because its composition can be identified, measured, is stable for storage, and has predictable behavior after administration (Thery et al., 2002; Chaput et al., 2004b).

The utilization of exosomes for cancer immunotherapy is a very new but very rapidly growing field. Most studies were conducted in vitro, but it is still unclear how oncologists will be able to translate the literature's data into the realm that will be most beneficial for the patient. One such complication is how the DEXs will be collected and implemented for patient treatment, and will the collected DEXs be sufficient enough? One potential strategy involves isolating DEXs through filtration of the patient's blood which will then be returned and employed to stimulate the immune system (Couzin, 2005). This would certainly allow for personalized therapy, but the question still remains: would there be enough DEXs and if not could adjuvant augmentation increase their numbers. Although the mode of exosome action in vivo is not clear yet, DEXs are a very interesting and potential substitute for dendritic cells in tumor vaccination therapy.

\section{Conclusion}

Various secreted extracellular vesicles have been found in blood, saliva, breast milk, bronchoalveolar lavage fluid, urine and amniotic fluid. Cellular uptake mechanisms have been shown to range from ligand/receptor interactions, integrin/cell adhesion molecule 
attachment and fusion, or through transcytosis. Physiologically, these extracellular vesicles have been shown to play a role in inter-cellular communication, disposal of defective or weakened proteins, formation of morphogen gradients for tissue patterning during development and for antigen presentation to T cells. Pathologically, these vesicles have been shown to aid in the transmission of viruses, prions, $\beta$-amyloid in Alzheimer's disease, and specifically to this chapter, tumor pathogenesis. Although additional investigation is still needed to fully exploit these extracellular vesicles for therapy, there is increasing evidence that in better understanding them and the molecules that they transport, determinations of diagnosis and prognosis and the prediction of response to treatment may be possible. However, it is also the hope that these vesicles may also act at therapeutic targets and perhaps even replacement therapies.

Conventional treatments for cancer include the use of chemotherapeutic drugs, radiation therapy and interventional surgery if the tumors are operable. Recent data suggests that the application of dendritic cell-derived, tumor cell-derived and even ascitic cell-derived exosomes could be developed as novel treatments for cancer. In fact, is has already been established that exosomes can be safely administered to patients, though the number of patients in these trials have been small and thus argue for larger studies. Furthermore, the goal of exosome therapy is to increase the biological magnitude of the immune response and as such exosomal immunotherapy is heavily reliant on the immune system. It will therefore be important to address issues such as patient immunosuppression due to therapeutic treatment, as the efficacy of the immunotherapy will be reliant upon the capability of the immune system. In order to increase the biological magnitude of the immune response researchers are artificially coating and engineering exosomes with tumor antigens to make them more recognizable to the immune system. The affects of heat shocking exosomes is also being investigated as heat shocked tumor exosomes are more effective than those not receiving heat treatment. Heating of the exosome confers a greater immunogenicity and thus elicits a greater immune response. Another possible application for exosomes is in vaccine delivery as exosome-producing cells could be engineered to produce a miRNA or specific genetic component or toxin that could be loaded into a exosome with the proper surface molecules for a cell specific uptake and response. Finally, the application of exosomes as immunotherapeutics represents a new chapter in cancer treatment development. However, much more research must go into elucidation of mechanism and targeting in order to improve potency.

\section{Acknowledgment}

The authors would like to thank the sponsors of their work on exosomes over the past few years: NCMHD Project EXPORT Program 5P20MD001632/Project 3 (NRW), also a generous start up package by Loma Linda University (NRW) and a National Merit Test Bed (NMTB) award sponsored by the Department of the Army under cooperative agreement number DAMD17-97-2-7016 (NRW).

\section{References}

Abusamra, A.J., Zhong, Z., Zheng, X., Li, M., Ichim, T.E., Chin, J.L. \& Min, W.P. (2005a) Tumor exosomes expressing Fas ligand mediate CD8+ T-cell apoptosis. Blood Cells, Molecules E Diseases, 35, 169-173. 
Abusamra, A.J., Zhong, Z., Zheng, X., Li, M., Ichim, T.E., Chin, J.L. \& Min, W.P. (2005b) Tumor exosomes expressing Fas ligand mediate CD8+ T-cell apoptosis. Blood Cells Mol Dis, 35, 169-173.

Adams, M., Navabi, H., Croston, D., Coleman, S., Tabi, Z., Clayton, A., Jasani, B. \& Mason, M.D. (2005) The rationale for combined chemo/immunotherapy using a Toll-like receptor 3 (TLR3) agonist and tumour-derived exosomes in advanced ovarian cancer. Vaccine, 23, 2374-2378.

Ahiru, O., Boutet, P., Fernandez-Messina, L., Aguera-Gonzalez, S., Skepper, J.N., ValesGomez, M. \& Reyburn, H.T. (2010) Natural killer cell cytotoxicity is suppressed by exposure to the human NKG2D ligand MICA*008 that is shed by tumor cells in exosomes. Cancer Research, 70, 481-489.

Al-Nedawi, K., Meehan, B., Micallef, J., Lhotak, V., May, L., Guha, A. \& Rak, J. (2008) Intercellular transfer of the oncogenic receptor EGFRvIII by microvesicles derived from tumour cells. Nat Cell Biol, 10, 619-624.

Al-Nedawi, K., Meehan, B. \& Rak, J. (2009) Microvesicles: messengers and mediators of tumor progression. Cell Cycle, 8, 2014-2018.

Albanese, J., Meterissian, S., Kontogiannea, M., Dubreuil, C., Hand, A., Sorba, S. \& Dainiak, N. (1998) Biologically active Fas antigen and its cognate ligand are expressed on plasma membrane-derived extracellular vesicles. Blood, 91, 3862-3874.

Anderson, H.C., Mulhall, D. \& Garimella, R. (2010) Role of extracellular membrane vesicles in the pathogenesis of various diseases, including cancer, renal diseases, atherosclerosis, and arthritis. Lab Invest, 90, 1549-1557.

Andre, F., Chaput, N., Schartz, N.E., Flament, C., Aubert, N., Bernard, J., Lemonnier, F., Raposo, G., Escudier, B., Hsu, D.H., Tursz, T., Amigorena, S., Angevin, E. \& Zitvogel, L. (2004) Exosomes as potent cell-free peptide-based vaccine. I. Dendritic cell-derived exosomes transfer functional MHC class I/peptide complexes to dendritic cells. J Immunol, 172, 2126-2136.

Andre, F., Schartz, N.E., Chaput, N., Flament, C., Raposo, G., Amigorena, S., Angevin, E. \& Zitvogel, L. (2002a) Tumor-derived exosomes: a new source of tumor rejection antigens. Vaccine, 20, A28-A31.

Andre, F., Schartz, N.E., Movassagh, M., Flament, C., Pautier, P., Morice, P., Pomel, C., Lhomme, C., Escudier, B., Le Chevalier, T., Tursz, T., Amigorena, S., Raposo, G., Angevin, E. \& Zitvogel, L. (2002b) Malignant effusions and immunogenic tumourderived exosomes. Lancet, 360, 295-305.

Andreola, G., Rivoltini, L., Castelli, C., Huber, V., Perego, P., Deho, P., Squarcina, P., Accornero, P., Lozupone, F., Lugini, L., Stringaro, A., Molinari, A., Arancia, G., Gentile, M., Parmiani, G. \& Fais, S. (2002) Induction of lymphocyte apoptosis by tumor cell secretion of FasL-bearing microvesicles. J Exp Med, 195, 1303-1316.

Arienti, G., Carlini, E., Verdacchi, R., Cosmi, E.V. \& Palmerini, C.A. (1997) Prostasome to sperm transfer of CD13/aminopeptidase N (EC 3.4.11.2). Biochim Biophys Acta, 1336, 533-538.

Babst, M. (2005) A protein's final ESCRT. Traffic, 6, 2-9.

Baj-Krzyworzeka, M., Szatanek, R., Weglarczyk, K., Baran, J., Urbanowicz, B., Branski, P., Ratajczak, M.Z. \& Zembala, M. (2006) Tumour-derived microvesicles carry several surface determinants and mRNA of tumour cells and transfer some of these determinants to monocytes. Cancer Immunol Immunother, 55, 808-818.

Bard, M.P., Hegmans, J.P., Hemmes, A., Luider, T.M., Willemsen, R., Severijnen, L.A., van Meerbeeck, J.P., Burgers, S.A., Hoogsteden, H.C. \& Lambrecht, B.N. (2004) 
Proteomic analysis of exosomes isolated from human malignant pleural effusions. Am J Respir Cell Mol Biol, 31, 114-121.

Bergsmedh, A., Szeles, A., Henriksson, M., Bratt, A., Folkman, M.J., Spetz, A.L. \& Holmgren, L. (2001) Horizontal transfer of oncogenes by uptake of apoptotic bodies. Proc Natl Acad Sci U S A, 98, 6407-6411.

Bhatnagar, S. \& Schorey, J.S. (2007) Exosomes released from infected macrophages contain Mycobacterium avium glycopeptidolipids and are proinflammatory. Journal of Biological Chemistry, 282, 25779-25789.

Bianco, N.R., Kim, S.H., Ruffner, M.A. \& Robbins, P.D. (2009) Therapeutic effect of exosomes from indoleamine 2,3-dioxygenase-positive dendritic cells in collagen-induced arthritis and delayed-type hypersensitivity disease models. Arthritis Rheum, 60, 380389.

Blanc, L. \& Vidal, M. (2010) Reticulocyte membrane remodeling: contribution of the exosome pathway. Curr Opin Hematol, 17, 177-183.

Carmeliet, P. (2005) VEGF as a key mediator of angiogenesis in cancer. Oncology, 69 Suppl 3, 4-10.

Celi, A., Lorenzet, R., Furie, B.C. \& Furie, B. (2004) Microparticles and a P-selectin-mediated pathway of blood coagulation. Dis Markers, 20, 347-352.

Chalmin, F., Ladoire, S., Mignot, G., Vincent, J., Bruchard, M., Remy-Martin, J.P., Boireau, W., Rouleau, A., Simon, B., Lanneau, D., De Thonel, A., Multhoff, G., Hamman, A., Martin, F., Chauffert, B., Solary, E., Zitvogel, L., Garrido, C., Ryffel, B., Borg, C., Apetoh, L., Rebe, C. \& Ghiringhelli, F. (2010) Membrane-associated Hsp72 from tumor-derived exosomes mediates STAT3-dependent immunosuppressive function of mouse and human myeloid-derived suppressor cells. The Journal of Clinical Investigation, 120, 457-471.

Chaput, N., Flament, C., Viaud, S., Taieb, J., Roux, S., Spatz, A., Andre, F., LePecq, J.B., Boussac, M., Garin, J., Amigorena, S., Thery, C. \& Zitvogel, L. (2006) Dendritic cell derived-exosomes: biology and clinical implementations. J Leukoc Biol, 80, 471-478.

Chaput, N., Schartz, N.E., Andre, F., Taieb, J., Novault, S., Bonnaventure, P., Aubert, N., Bernard, J., Lemonnier, F., Merad, M., Adema, G., Adams, M., Ferrantini, M., Carpentier, A.F., Escudier, B., Tursz, T., Angevin, E. \& Zitvogel, L. (2004a) Exosomes as potent cell-free peptide-based vaccine. II. Exosomes in CpG adjuvants efficiently prime naive Tc1 lymphocytes leading to tumor rejection. J Immunol, 172, 2137-2146.

Chaput, N., Taieb, J., Schartz, N.E., Andre, F., Angevin, E. \& Zitvogel, L. (2004b) Exosomebased immunotherapy. Cancer Immunol Immunother, 53, 234-239.

Chen, K.G., Valencia, J.C., Lai, B., Zhang, G., Paterson, J.K., Rouzaud, F., Berens, W., Wincovitch, S.M., Garfield, S.H., Leapman, R.D., Hearing, V.J. \& Gottesman, M.M. (2006a) Melanosomal sequestration of cytotoxic drugs contributes to the intractability of malignant melanomas. Proc Natl Acad Sci U S A, 103, 9903-9907.

Chen, S.Q., Du, Y., Wang, X., Gu, Q.L., Huang, Y.M. \& Dong, Z.M. (2006b) [Production of specific CTL induced by exosomes derived from K562 cells]. Zhongguo Shi Yan Xue Ye Xue Za Zhi, 14, 1168-1171.

Chen, W., Wang, J., Shao, C., Liu, S., Yu, Y., Wang, Q. \& Cao, X. (2006c) Efficient induction of antitumor $\mathrm{T}$ cell immunity by exosomes derived from heat-shocked lymphoma cells. European Journal of Immunology, 36, 1598-1607. 
Choi, D.S., Lee, J.M., Park, G.W., Lim, H.W., Bang, J.Y., Kim, Y.K., Kwon, K.H., Kwon, H.J., Kim, K.P. \& Gho, Y.S. (2007) Proteomic analysis of microvesicles derived from human colorectal cancer cells. J Proteome Res, 6, 4646-4655.

Clayton, A., Mitchell, J.P., Court, J., Linnane, S., Mason, M.D. \& Tabi, Z. (2008) Human tumor-derived exosomes down-modulate NKG2D expression. Journal of Immunology, 180, 7249-7258.

Clayton, A., Mitchell, J.P., Court, J., Mason, M.D. \& Tabi, Z. (2007) Human tumor-derived exosomes selectively impair lymphocyte responses to interleukin-2. Cancer Res, 67, 7458-7466.

Couzin, J. (2005) Cell biology: The ins and outs of exosomes. Science, 308, 1862-1863.

Dashevsky, O., Varon, D. \& Brill, A. (2009) Platelet-derived microparticles promote invasiveness of prostate cancer cells via upregulation of MMP-2 production. Int J Cancer, 124, 1773-1777.

de Gassart, A., Geminard, C., Fevrier, B., Raposo, G. \& Vidal, M. (2003) Lipid raft-associated protein sorting in exosomes. Blood, 102, 4336-4344.

Del Conde, I., Shrimpton, C.N., Thiagarajan, P. \& Lopez, J.A. (2005) Tissue-factor-bearing microvesicles arise from lipid rafts and fuse with activated platelets to initiate coagulation. Blood, 106, 1604-1611.

Di Vizio, D., Kim, J., Hager, M.H., Morello, M., Yang, W., Lafargue, C.J., True, L.D., Rubin, M.A., Adam, R.M., Beroukhim, R., Demichelis, F. \& Freeman, M.R. (2009) Oncosome formation in prostate cancer: association with a region of frequent chromosomal deletion in metastatic disease. Cancer Res, 69, 5601-5609.

Dolo, V., D'Ascenzo, S., Giusti, I., Millimaggi, D., Taraboletti, G. \& Pavan, A. (2005) Shedding of membrane vesicles by tumor and endothelial cells. Ital J Anat Embryol, 110, 127-133.

Dong-Sic, C., Jae-Min, L., Wook, P., Hyeon-Woo, L., Young, B., Yoon-Keun, K., KyungHoon, K., Jeong, K., Pyo, K. \& Song, Y. (2007) Proteomic analysis of microvesicles derived from human colorectal cancer cells. J Proteo Res, 6, 10.

Duijvesz, D., Luider, T., Bangma, C.H. \& Jenster, G. (2010) Exosomes as Biomarker Treasure Chests for Prostate Cancer. Eur Urol.

Escudier, B., Dorval, T., Chaput, N., Andre, F., Caby, M.P., Novault, S., Flament, C., Leboulaire, C., Borg, C., Amigorena, S., Baccaccio, C., Bonnerot, C., Dhellin, O., Movassagh, M., Piperno, S., Robert, C., Serra, V., Valente, N., LePecq, J.B., Spatz, A., Lantz, O., Tursz, T., Angevin, E. \& Zitvogel, L. (2005) Vaccination of metastatic melanoma patients with autologous dendritic cell (DC) derived-exosomes: results of the first phase I clinical trial. Journal of Translational Medicine, 3.

Falati, S., Liu, Q., Gross, P., Merrill-Skoloff, G., Chou, J., Vandendries, E., Celi, A., Croce, K., Furie, B.C. \& Furie, B. (2003) Accumulation of tissue factor into developing thrombi in vivo is dependent upon microparticle P-selectin glycoprotein ligand 1 and platelet P-selectin. J Exp Med, 197, 1585-1598.

Gesierich, S., Berezovskiy, I., Ryschich, E. \& Zoller, M. (2006) Systemic induction of the angiogenesis switch by the tetraspanin D6.1A/CO-029. Cancer Res, 66, 7083-7094.

Ghosh, A.K., Secreto, C.R., Knox, T.R., Ding, W., Mukhopadhyay, D. \& Kay, N.E. (2010) Circulating microvesicles in B-cell chronic lymphocytic leukemia can stimulate marrow stromal cells: implications for disease progression. Blood, 115, 1755-1764.

Ginestra, A., La Placa, M.D., Saladino, F., Cassara, D., Nagase, H. \& Vittorelli, M.L. (1998) The amount and proteolytic content of vesicles shed by human cancer cell lines correlates with their in vitro invasiveness. Anticancer Res, 18, 3433-3437. 
Ginestra, A., Miceli, D., Dolo, V., Romano, F.M. \& Vittorelli, M.L. (1999) Membrane vesicles in ovarian cancer fluids: a new potential marker. Anticancer Res, 19, 3439-3445.

Graves, L.E., Ariztia, E.V., Navari, J.R., Matzel, H.J., Stack, M.S. \& Fishman, D.A. (2004) Proinvasive properties of ovarian cancer ascites-derived membrane vesicles. Cancer Res, 64, 7045-7049.

Haubold, K., Rink, M., Spath, B., Friedrich, M., Chun, F.K., Marx, G., Amirkhosravi, A., Francis, J.L., Bokemeyer, C., Eifrig, B. \& Langer, F. (2009) Tissue factor procoagulant activity of plasma microparticles is increased in patients with earlystage prostate cancer. Thromb Haemost, 101, 1147-1155.

Hegmans, J.P., Bard, M.P., Hemmes, A., Luider, T.M., Kleijmeer, M.J., Prins, J.B., Zitvogel, L., Burgers, S.A., Hoogsteden, H.C. \& Lambrecht, B.N. (2004) Proteomic analysis of exosomes secreted by human mesothelioma cells. Am J Pathol, 164, 1807-1815.

Hendrix, A., Westbroek, W., Bracke, M. \& De Wever, O. (2010) An ex(o)citing machinery for invasive tumor growth. Cancer Res, 70, 9533-9537.

Hotary, K.B., Allen, E.D., Brooks, P.C., Datta, N.S., Long, M.W. \& Weiss, S.J. (2003) Membrane type I matrix metalloproteinase usurps tumor growth control imposed by the three-dimensional extracellular matrix. Cell, 114, 33-45.

Huber, V., Fais, S., Iero, M., Lugini, L., Canese, P., Squarcina, P., Zaccheddu, A., Colone, M., Arancia, G., Gentile, M., Seregni, E., Valenti, R., Ballabio, G., Belli, F., Leo, E., Parmiani, G. \& Rivoltini, L. (2005) Human colorectal cancer cells induce T-cell death through release of proapoptotic microvesicles: role in immune escape. Gastroenterology, 128, 1796-1804.

Iero, M., Valenti, R., Huber, V., Filipazzi, P., Parmiani, G., Fais, S. \& Rivoltini, L. (2008) Tumour-released exosomes and their implications in cancer immunity. Cell Death Differ, 15, 80-88.

Janowska-Wieczorek, A., Majka, M., Kijowski, J., Baj-Krzyworzeka, M., Reca, R., Turner, A.R., Ratajczak, J., Emerson, S.G., Kowalska, M.A. \& Ratajczak, M.Z. (2001) Plateletderived microparticles bind to hematopoietic stem/progenitor cells and enhance their engraftment. Blood, 98, 3143-3149.

Janowska-Wieczorek, A., Wysoczynski, M., Kijowski, J., Marquez-Curtis, L., Machalinski, B., Ratajczak, J. \& Ratajczak, M.Z. (2005) Microvesicles derived from activated platelets induce metastasis and angiogenesis in lung cancer. Int J Cancer, 113, 752-760.

Jansen, F.H., Krijgsveld, J., van Rijswijk, A., van den Bemd, G.J., van den Berg, M.S., van Weerden, W.M., Willemsen, R., Dekker, L.J., Luider, T.M. \& Jenster, G. (2009) Exosomal secretion of cytoplasmic prostate cancer xenograft-derived proteins. Mol Cell Proteomics, 8, 1192-1205.

Johnstone, R.M., Adam, M., Hammond, J.R., Orr, L. \& Turbide, C. (1987) Vesicle formation during reticulocyte maturation. Association of plasma membrane activities with released vesicles (exosomes). J Biol Chem, 262, 9412-9420.

Jung, T., Castellana, D., Klingbeil, P., Cuesta Hernandez, I., Vitacolonna, M., Orlicky, D.J., Roffler, S.R., Brodt, P. \& Zoller, M. (2009) CD44v6 dependence of premetastatic niche preparation by exosomes. Neoplasia, 11, 1093-1105.

Keller, S., Konig, A.K., Marme, F., Runz, S., Wolterink, S., Koensgen, D., Mustea, A., Sehouli, J. \& Altevogt, P. (2009) Systemic presence and tumor-growth promoting effect of ovarian carcinoma released exosomes. Cancer Lett, 278, 73-81.

Keller, S., Sanderson, M.P., Stoeck, A. \& Altevogt, P. (2006) Exosomes: from biogenesis and secretion to biological function. Immunol Lett, 107, 102-108.

Kerbel, R.S. (2008) Tumor angiogenesis. N Engl J Med, 358, 2039-2049. 
Khan, S., Jutzy, J.M., Aspe, J.R., McGregor, D.W., Neidigh, J.W. \& Wall, N.R. (2011) Survivin is released from cancer cells via exosomes. Apoptosis, 16, 1-12.

Kim, J.V., Latouche, J.B., Riviere, I. \& Sadelain, M. (2004) The ABCs of artificial antigen presentation. Nature Biotechnology, 22, 403-410.

Kim, J.W., Wieckowski, E., Taylor, D.D., Reichert, T.E., Watkins, S. \& Whiteside, T.L. (2005) Fas ligand-positive membranous vesicles isolated from sera of patients with oral cancer induce apoptosis of activated T lymphocytes. Clin Cancer Res, 11, 1010-1020.

Koga, K., Matsumoto, K., Akiyoshi, T., Kubo, M., Yamanaka, N., Tasaki, A., Nakashima, H., Nakamura, M., Kuroki, S., Tanaka, M. \& Katano, M. (2005) Purification, characterization and biological significance of tumor-derived exosomes. Anticancer Res, 25, 3703-3707.

Koyama, S., Koike, N. \& Adachi, S. (2001) Fas receptor counterattack against tumorinfiltrating lymphocytes in vivo as a mechanism of immune escape in gastric carcinoma. Journal of Cancer Research and Clinical Oncology, 127, 20-26.

Lehmann, B.D., Paine, M.S., Brooks, A.M., McCubrey, J.A., Renegar, R.H., Wang, R. \& Terrian, D.M. (2008) Senescence-associated exosome release from human prostate cancer cells. Cancer Res, 68, 7864-7871.

Leroyer, A.S., Tedgui, A. \& Boulanger, C.M. (2008) Role of microparticles in atherothrombosis. J Intern Med, 263, 528-537.

Lespagnol, A., Duflaut, D., Beekman, C., Blanc, L., Fiucci, G., Marine, J.C., Vidal, M., Amson, R. \& Telerman, A. (2008) Exosome secretion, including the DNA damage-induced p53-dependent secretory pathway, is severely compromised in TSAP6/Steap3-null mice. Cell Death Differ, 15, 1723-1733.

Liu, C., Yu, S., Zinn, K., Wang, J., Zhang, L., Jia, Y., Kappes, J.C., Barnes, S., Kimberly, R.P., Grizzle, W.E. \& Zhang, H.G. (2006) Murine mammary carcinoma exosomes promote tumor growth by suppression of NK cell function. J Immunol, 176, 13751385.

Losche, W., Scholz, T., Temmler, U., Oberle, V. \& Claus, R.A. (2004) Platelet-derived microvesicles transfer tissue factor to monocytes but not to neutrophils. Platelets, 15 , 109-115.

Lu, Q., Zhang, J., Allison, R., Gay, H., Yang, W.X., Bhowmick, N.A., Frelix, G., Shappell, S. \& Chen, Y.H. (2009) Identification of extracellular delta-catenin accumulation for prostate cancer detection. Prostate, 69, 411-418.

Luhtala, N. \& Odorizzi, G. (2004) Bro1 coordinates deubiquitination in the multivesicular body pathway by recruiting Doa4 to endosomes. J Cell Biol, 166, 717-729.

Mack, M., Kleinschmidt, A., Bruhl, H., Klier, C., Nelson, P.J., Cihak, J., Plachy, J., Stangassinger, M., Erfle, V. \& Schlondorff, D. (2000) Transfer of the chemokine receptor CCR5 between cells by membrane-derived microparticles: a mechanism for cellular human immunodeficiency virus 1 infection. Nat Med, 6, 769-775.

Martinez-Lostao, L., Garcia-Alvarez, F., Basanez, G., Alegre-Aguaron, E., Desportes, P., Larrad, L., Naval, J., Martinez-Lorenzo, M.J. \& Anel, A. (2010) Liposome-bound APO2L/TRAIL is an effective treatment in a rabbit model of rheumatoid arthritis. Arthritis Rheum, 62, 2272-2282.

Mathivanan, S., Lim, J.W., Tauro, B.J., Ji, H., Moritz, R.L. \& Simpson, R.J. (2010) Proteomics analysis of A33 immunoaffinity-purified exosomes released from the human colon tumor cell line LIM1215 reveals a tissue-specific protein signature. Mol Cell Proteomics, 9, 197-208. 
Matsuo, H., Chevallier, J., Mayran, N., Le Blanc, I., Ferguson, C., Faure, J., Blanc, N.S., Matile, S., Dubochet, J., Sadoul, R., Parton, R.G., Vilbois, F. \& Gruenberg, J. (2004) Role of LBPA and Alix in multivesicular liposome formation and endosome organization. Science, 303, 531-534.

Mears, R., Craven, R.A., Hanrahan, S., Totty, N., Upton, C., Young, S.L., Patel, P., Selby, P.J. \& Banks, R.E. (2004) Proteomic analysis of melanoma-derived exosomes by twodimensional polyacrylamide gel electrophoresis and mass spectrometry. Proteomics, 4, 4019-4031.

Mignot, G., Roux, S., Thery, C., Segura, E. \& Zitvogel, L. (2006) Prospects for exosomes in immunotherapy of cancer. J Cell Mol Med, 10, 376-388.

Milsom, C., Yu, J., May, L., Meehan, B., Magnus, N., Al-Nedawi, K., Luyendyk, J., Weitz, J., Klement, P., Broze, G., Mackman, N. \& Rak, J. (2007) The role of tumor-and hostrelated tissue factor pools in oncogene-driven tumor progression. Thromb Res, 120 Suppl 2, S82-91.

Mitchell, P.J., Welton, J., Staffurth, J., Court, J., Mason, M.D., Tabi, Z. \& Clayton, A. (2009) Can urinary exosomes act as treatment response markers in prostate cancer? J Transl Med, 7, 4 .

Morse, M.A., Garst, J., Osada, T., Khan, S., Hobeika, A., Clay, T.M., Valente, N., Shreeniwas, R., Sutton, M.A., Delcayre, A., Hsu, D.H., LePecq, J.B. \& Lyerly, H.K. (2005) A phase I study of dexosome immunotherapy in patients with advanced non-small cell lung cancer. Journal of Translational Medicine, 3.

Muralidharan-Chari, V., Clancy, J.W., Sedgwick, A. \& D'Souza-Schorey, C. (2010) Microvesicles: mediators of extracellular communication during cancer progression. J Cell Sci, 123, 1603-1611.

Nickel, W. (2003) The mystery of nonclassical protein secretion. A current view on cargo proteins and potential export routes. Eur J Biochem, 270, 2109-2119.

Nieuwland, R. \& Sturk, A. (2010) Why do cells release vesicles? Thromb Res, 125 Suppl 1, S49-51.

Nilsson, J., Skog, J., Nordstrand, A., Baranov, V., Mincheva-Nilsson, L., Breakefield, X.O. \& Widmark, A. (2009) Prostate cancer-derived urine exosomes: a novel approach to biomarkers for prostate cancer. Br J Cancer, 100, 1603-1607.

Obregon, C., Rothen-Rutishauser, B., Gitahi, S.K., Gehr, P. \& Nicod, L.P. (2006) Exovesicles from human activated dendritic cells fuse with resting dendritic cells, allowing them to present alloantigens. American Journal of Pathology, 169, 2127-2136.

Osterud, B. (2003) The role of platelets in decrypting monocyte tissue factor. Dis Mon, 49, 713.

Pap, E., Pallinger, E. \& Falus, A. (2010) The role of membrane vesicles in tumorigenesis. Crit Rev Oncol Hematol.

Park, D., Tosello-Trampont, A.C., Elliott, M.R., Lu, M., Haney, L.B., Ma, Z., Klibanov, A.L., Mandell, J.W. \& Ravichandran, K.S. (2007) BAI1 is an engulfment receptor for apoptotic cells upstream of the ELMO/Dock180/Rac module. Nature, 450, 430-434.

Parolini, I., Federici, C., Raggi, C., Lugini, L., Palleschi, S., De Milito, A., Coscia, C., Iessi, E., Logozzi, M., Molinari, A., Colone, M., Tatti, M., Sargiacomo, M. \& Fais, S. (2009) Microenvironmental $\mathrm{pH}$ is a key factor for exosome traffic in tumor cells. J Biol Chem, 284, 34211-34222.

Ponnambalam, S. \& Baldwin, S.A. (2003) Constitutive protein secretion from the trans-Golgi network to the plasma membrane. Mol Membr Biol, 20, 129-139. 
Raimondo, F., Morosi, L., Chinello, C., Magni, F. \& Pitto, M. (2011) Advances in membranous vesicle and exosome proteomics improving biological understanding and biomarker discovery. Proteomics, 11, 709-720.

Rak, J. (2010) Microparticles in cancer. Semin Thromb Hemost, 36, 888-906.

Raposo, G., Nijman, H.W., Stoorvogel, W., Liejendekker, R., Harding, C.V., Melief, C.J. \& Geuze, H.J. (1996) B lymphocytes secrete antigen-presenting vesicles. J Exp Med, $183,1161-1172$.

Ratajczak, J., Wysoczynski, M., Hayek, F., Janowska-Wieczorek, A. \& Ratajczak, M.Z. (2006) Membrane-derived microvesicles: important and underappreciated mediators of cell-to-cell communication. Leukemia, 20, 1487-1495.

Record, M., Subra, C., Silvente-Poirot, S. \& Poirot, M. (2011) Exosomes as intercellular signalosomes and pharmacological effectors. Biochem Pharmacol.

Ronquist, G. \& Brody, I. (1985) The prostasome: its secretion and function in man. Biochim Biophys Acta, 822, 203-218.

Ronquist, G. \& Frithz, G.G. (1986) Prostasomes in human semen contain ADP and GDP. Acta Eur Fertil, 17, 273-276.

Rooney, I.A., Atkinson, J.P., Krul, E.S., Schonfeld, G., Polakoski, K., Saffitz, J.E. \& Morgan, B.P. (1993) Physiologic relevance of the membrane attack complex inhibitory protein CD59 in human seminal plasma: CD59 is present on extracellular organelles (prostasomes), binds cell membranes, and inhibits complement-mediated lysis. J Exp Med, 177, 1409-1420.

Safaei, R., Larson, B.J., Cheng, T.C., Gibson, M.A., Otani, S., Naerdemann, W. \& Howell, S.B. (2005) Abnormal lysosomal trafficking and enhanced exosomal export of cisplatin in drug-resistant human ovarian carcinoma cells. Mol Cancer Ther, 4, 1595-1604.

Sanderson, M.P., Keller, S., Alonso, A., Riedle, S., Dempsey, P.J. \& Altevogt, P. (2008) Generation of novel, secreted epidermal growth factor receptor (EGFR/ErbB1) isoforms via metalloprotease-dependent ectodomain shedding and exosome secretion. J Cell Biochem, 103, 1783-1797.

Savina, A., Furlan, M., Vidal, M. \& Colombo, M.I. (2003) Exosome release is regulated by a calcium-dependent mechanism in K562 cells. J Biol Chem, 278, 20083-20090.

Schiller, M., Bekeredjian-Ding, I., Heyder, P., Blank, N., Ho, A.D. \& Lorenz, H.M. (2008) Autoantigens are translocated into small apoptotic bodies during early stages of apoptosis. Cell Death Differ, 15, 183-191.

Schorey, J.S. \& Bhatnagar, S. (2008) Exosome function: from tumor immunology to pathogen biology. Traffic, 9, 871-881.

Shedden, K., Xie, X.T., Chandaroy, P., Chang, Y.T. \& Rosania, G.R. (2003) Expulsion of small molecules in vesicles shed by cancer cells: association with gene expression and chemosensitivity profiles. Cancer Res, 63, 4331-4337.

Simpson, R.J., Jensen, S.S. \& Lim, J.W. (2008) Proteomic profiling of exosomes: current perspectives. Proteomics, 8, 4083-4099.

Simpson, R.J., Lim, J.W., Moritz, R.L. \& Mathivanan, S. (2009) Exosomes: proteomic insights and diagnostic potential. Expert Rev Proteomics, 6, 267-283.

Skog, J., Wurdinger, T., van Rijn, S., Meijer, D.H., Gainche, L., Sena-Esteves, M., Curry, W.T., Jr., Carter, B.S., Krichevsky, A.M. \& Breakefield, X.O. (2008) Glioblastoma microvesicles transport RNA and proteins that promote tumour growth and provide diagnostic biomarkers. Nat Cell Biol, 10, 1470-1476. 
Skokos, D., Le Panse, S., Villa, I., Rousselle, J.C., Peronet, R., David, B., Namane, A. \& Mecheri, S. (2001) Mast cell-dependent B and T lymphocyte activation is mediated by the secretion of immunologically active exosomes. J Immunol, 166, 868-876.

Smalley, D.M., Sheman, N.E., Nelson, K. \& Theodorescu, D. (2008) Isolation and identification of potential urinary microparticle biomarkers of bladder cancer. $J$ Proteome Res, 7, 2088-2096.

Szajnik, M., Czystowska, M., Szczepanski, M.J., Mandapathil, M. \& Whiteside, T.L. (2010) Tumor-derived microvesicles induce, expand and up-regulate biological activites of human regulatory T cells (Treg). PLoS One, 5, e11469.

Tan, A., De La Pena, H. \& Seifalian, A.M. (2010) The application of exosomes as a nanoscale cancer vaccine. Int J Nanomedicine, 5, 889-900.

Taraboletti, G., D'Ascenzo, S., Giusti, I., Marchetti, D., Borsotti, P., Millimaggi, D., Giavazzi, R., Pavan, A. \& Dolo, V. (2006) Bioavailability of VEGF in tumor-shed vesicles depends on vesicle burst induced by acidic $\mathrm{pH}$. Neoplasia, 8, 96-103.

Taylor, D.D., Akyol, S. \& Gercel-Taylor, C. (2006) Pregnancy-associated exosomes and their modulation of T cell signaling. J Immunol, 176, 1534-1542.

Taylor, D.D. \& Gercel-Taylor, C. (2005) Tumour-derived exosomes and their role in cancerassociated T-cell signalling defects. Br J Cancer, 92, 305-311.

Tesselaar, M.E., Romijn, F.P., Van Der Linden, I.K., Prins, F.A., Bertina, R.M. \& Osanto, S. (2007) Microparticle-associated tissue factor activity: a link between cancer and thrombosis? J Thromb Haemost, 5, 520-527.

Thery, C., Amigorena, S., Raposo, G. \& Clayton, A. (2006) Isolation and characterization of exosomes from cell culture supernatants and biological fluids. Curr Protoc Cell Biol, Chapter 3, Unit 322.

Thery, C., Duban, L., Segura, E., Veron, P., Lantz, O. \& Amigorena, S. (2002) Indirect activation of naive CD4+ T cells by dendritic cell-derived exosomes. Nat Immunol, 3, 1156-1162.

Thery, C., Ostrowski, M. \& Segura, E. (2009) Membrane vesicles as conveyors of immune responses. Nat Rev Immunol, 9, 581-593.

Thomas, G.M., Panicot-Dubois, L., Lacroix, R., Dignat-George, F., Lombardo, D. \& Dubois, C. (2009) Cancer cell-derived microparticles bearing P-selectin glycoprotein ligand 1 accelerate thrombus formation in vivo. J Exp Med, 206, 1913-1927.

Valadi, H., Ekstrom, K., Bossios, A., Sjostrand, M., Lee, J.J. \& Lotvall, J.O. (2007) Exosomemediated transfer of mRNAs and microRNAs is a novel mechanism of genetic exchange between cells. Nat Cell Biol, 9, 654-659.

Valenti, R., Huber, V., Iero, M., Filipazzi, P., Parmiani, G. \& Rivoltini, L. (2007) Tumorreleased microvesicles as vehicles of immunosuppression. Cancer Res, 67, 2912-2915.

van Niel, G., Porto-Carreiro, I., Simoes, S. \& Raposo, G. (2006) Exosomes: a common pathway for a specialized function. J Biochem, 140, 13-21.

Vella, L.J., Greenwood, D.L., Cappai, R., Scheerlinck, J.P. \& Hill, A.F. (2008) Enrichment of prion protein in exosomes derived from ovine cerebral spinal fluid. Vet Immunol Immunopathol, 124, 385-393.

Viaud, S., Terme, M., Flament, C., Taieb, J., Andre, F., Novault, S., Escudier, B., Robert, C., Caillat-Zucman, S., Tursz, T., Zitvogel, L. \& Chaput, N. (2009) Dendritic cellderived exosomes promote natural killer cell activation and proliferation: a role for NKG2D ligands and IL-15Ralpha. PLoS One, 4, e4942. 
Welton, J.L., Khanna, S., Giles, P.J., Brennan, P., Brewis, I.A., Staffurth, J., Mason, M.D. \& Clayton, A. (2010) Proteomics analysis of bladder cancer exosomes. Mol Cell Proteomics, 9, 1324-1338.

Wieckowski, E. \& Whiteside, T.L. (2006) Human tumor-derived vs dendritic cell-derived exosomes have distinct biologic roles and molecular profiles. Immunol Res, 36, 247254.

Wolfers, J., Lozier, A., Raposo, G., Regnault, A., Thery, C., Masurier, C., Flament, C., Pouzieux, S., Faure, F., Tursz, T., Angevin, E., Amigorena, S. \& Zitvogel, L. (2001) Tumor-derived exosomes are a source of shared tumor rejection antigens for CTL cross-priming. Nat Med, 7, 297-303.

Xiang, X., Poliakov, A., Liu, C., Liu, Y., Deng, Z.B., Wang, J., Cheng, Z., Shah, S.V., Zhang, L., Grizzle, W.E., Mobley, J. \& Zhange, H.G. (2009) Induction of myeloid-derived suppressor cells by tumor exosomes. International Journal of Cancer, 124, 2621-2633.

Xiao, Z., Blonder, J., Zhou, M. \& Veenstra, T.D. (2009) Proteomic analysis of extracellular matrix and vesicles. J Proteomics, 72, 34-45.

Yu, J.L., May, L., Lhotak, V., Shahrzad, S., Shirasawa, S., Weitz, J.I., Coomber, B.L., Mackman, N. \& Rak, J.W. (2005) Oncogenic events regulate tissue factor expression in colorectal cancer cells: implications for tumor progression and angiogenesis. Blood, 105, 1734-1741.

Yu, X., Harris, S.L. \& Levine, A.J. (2006) The regulation of exosome secretion: a novel function of the p53 protein. Cancer Res, 66, 4795-4801.

Yu, X., Riley, T. \& Levine, A.J. (2009) The regulation of the endosomal compartment by p53 the tumor suppressor gene. FEBS J, 276, 2201-2212.

Zhang, H., Xie, Y., Li, W., Chibbar, R., Xiong, S. \& Xiang, J. (2011) CD4+ T cell-released exosomes inhibit $\mathrm{CD} 8+$ cytotoxic T-lymphocyte responses and antitumor immunity. Cellular \& Molecular Immunology, 8, 23-30.

Zhao, C.Q., Li, T.L., He, S.H., Chen, X., An, Y.F., Wu, W.K., Zhou, X.H., Li, P. \& Yang, P.C. (2010) Specific immunotherapy suppresses Th2 responses via modulating TIM1/TIM4 interaction on dendritic cells. Allergy, 65, 986-995.

Zhou, H., Cheruvanky, A., Hu, X., Matsumoto, T., Hiramatsu, N., Cho, M.E., Berger, A., Leelahavanichkul, A., Doi, K., Chawla, L.S., Illei, G.G., Kopp, J.B., Balow, J.E., Austin, H.A., 3rd, Yuen, P.S. \& Star, R.A. (2008) Urinary exosomal transcription factors, a new class of biomarkers for renal disease. Kidney Int, 74, 613-621.

Zitvogel, L., Regnault, A., Lozier, A., Wolfers, J., Flament, C., Tenza, D., RicciardiCastagnoli, P., Raposo, G. \& Amigorena, S. (1998) Eradication of established murine tumors using a novel cell-free vaccine: dendritic cell-derived exosomes. Nat Med, 4, 594-600. 


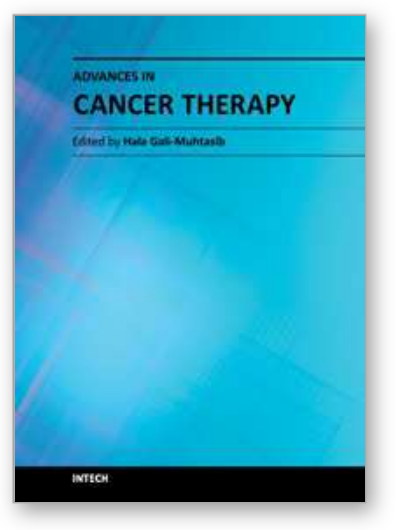

\author{
Advances in Cancer Therapy \\ Edited by Prof. Hala Gali-Muhtasib
}

ISBN 978-953-307-703-1

Hard cover, 568 pages

Publisher InTech

Published online 21, November, 2011

Published in print edition November, 2011

The book "Advances in Cancer Therapy" is a new addition to the Intech collection of books and aims at providing scientists and clinicians with a comprehensive overview of the state of current knowledge and latest research findings in the area of cancer therapy. For this purpose research articles, clinical investigations and review papers that are thought to improve the readers' understanding of cancer therapy developments and/or to keep them up to date with the most recent advances in this field have been included in this book. With cancer being one of the most serious diseases of our times, I am confident that this book will meet the patients', physicians' and researchers' needs.

\title{
How to reference
}

In order to correctly reference this scholarly work, feel free to copy and paste the following:

Khan Salma, Jutzy Jessica M.S., Aspe Jonathan R., Valenzuela Malyn May A., Park Joon S., Turay David and Wall Nathan R. (2011). The Application of Membrane Vesicles for Cancer Therapy, Advances in Cancer Therapy, Prof. Hala Gali-Muhtasib (Ed.), ISBN: 978-953-307-703-1, InTech, Available from: http://www.intechopen.com/books/advances-in-cancer-therapy/the-application-of-membrane-vesicles-forcancer-therapy

\section{INTECH}

open science | open minds

\section{InTech Europe}

University Campus STeP Ri Slavka Krautzeka 83/A 51000 Rijeka, Croatia Phone: +385 (51) 770447 Fax: +385 (51) 686166 www.intechopen.com

\author{
InTech China \\ Unit 405, Office Block, Hotel Equatorial Shanghai \\ No.65, Yan An Road (West), Shanghai, 200040, China \\ 中国上海市延安西路65号上海国际贵都大饭店办公楼405单元 \\ Phone: +86-21-62489820 \\ Fax: +86-21-62489821
}


(C) 2011 The Author(s). Licensee IntechOpen. This is an open access article distributed under the terms of the Creative Commons Attribution 3.0 License, which permits unrestricted use, distribution, and reproduction in any medium, provided the original work is properly cited. 